\title{
Geological overview of the Angola-Congo margin, the Congo deep-sea fan and its submarine valleys
}

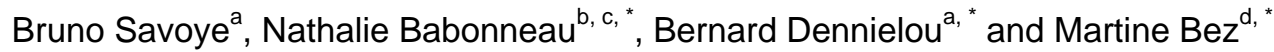

\author{
a IFREMER, "Environnements Sédimentaires" Laboratory, Marine Geosciences, BP 70, 29280 Plouzané, France \\ b Université Européenne de Bretagne, Brest, 29280 Plouzané, France \\ c Université de Brest, CNRS UMR 6538 "Domaines Océaniques", IUEM, Place Nicolas Copernic, 29280 \\ Plouzané, France. \\ d TOTAL, CSTJF Avenue Larribau, 64018 Pau Cedex, France \\ *: Corresponding author : Nathalie Babonneau, Tel.: +2 984987 23, email address : nathalie.babonneau@univ- \\ $\underline{\text { brest.fr }}$ \\ Email address: Bernard.Dennielou@ifremer.fr, Martine.BEZ@total.com
}

\begin{abstract}
:
The Congo deep-sea fan is one of the largest fans in the world still affected by presently active turbidity currents. The present activity of deep-sea sedimentary processes is linked to the existence of a direct connection between the Congo River estuary and the Congo canyon head that allows relatively continuous sediment feeding of the deep-sea environment, in spite of a wide continental shelf $(150 \mathrm{~km})$. Because of this important activity in terms of sedimentary processes, the deep-sea environment of the Congo-Angola margin presents major interests concerning physical, chemical and biological studies near the seafloor.

The main aim of this paper is to present the initial geological context of the BioZaire Program, showing a synthesis of the major results of the ZaïAngo Project including (1) the brief geological setting of the Congo-Angola margin, (2) the structure of the modern Congo deep-sea fan, (3) the sedimentary architecture of the recent Congo turbidite system (from the canyon to the distal lobes) and (4) the recent and present turbidite sedimentation. In order to provide useful information and advice relevant to biological and geochemical studies across the Congo sedimentary system, this article is particularly focused on the present sedimentary processes and the present activity of turbidity current along the Congo canyon and channel.
\end{abstract}

Keywords: Congo-Angola margin; Congo channel; Sedimentary deposits; Turbidite 


\section{.1 Introduction}

The accumulation of marine sediment seaward of the Congo River estuary is probably one of the greatest in the world for a submarine system that is still active today. In the continental domain, the Congo sedimentary system is composed by a wide drainage basin, the river and its tributaries. In the nearshore and marine domain: it consists of the estuary, the canyon, which acts mainly as a by-pass zone, and finally an area of preferential sedimentation at the foot of the continental slope and in the deep basin. The Congo submarine system has been geologically studied since Buchanan in 1887 (submarine cable survey) and was the focus of the ZaïAngo project team from 1998 to 2005. Several types of evidence of Holocene and very recent activity in the canyon have been described and linked to sedimentary processes such as turbidity currents, river floods, slides, gas hydrate formation and fluid escape. The aim of this paper is to synthesize the geological knowledge of the area and in particular the results of the ZaïAngo project in order to provide useful information and advice relevant to biological and geochemical studies across the Congo sedimentary system.

Marine biologists and oceanographers are usually not familiar with turbidite deposits. These sedimentary deposits were first recognised and described in outcrops of ancient sedimentary series (Bouma, 1962; Walker, 1978; Mutti, 1992). They are generated by submarine gravity processes and they build large sedimentary systems in deep-water environments, termed deep-sea fans. Deep-sea fans are well developed from the foot of the continental slope to different water depths in the abyssal plain. They vary in size, structure and morphology. Most are fed by one or more canyons, located at the prolongation of the mouth of fluvial systems (estuary, delta...). Recent improvements in high-resolution bathymetry, marine seismic systems, deep-tow sonar and cores have made it possible to explore deep-water environments and to study modern deepsea fans in great detail.

The Congo deep-sea fan with the Congo canyon and submarine valleys are major morphological features of the western African margin. The fan constitutes the major depocenter of the southeastern Atlantic Ocean and is among the largest modern deep-sea fans in the world. The fan developed during the post-rift evolution of the continental margin of west-equatorial Africa. It is currently fed by the Congo River, whose continental drainage area is the second largest in the world (Van Weering and Van Iperen, 1984) (Fig. 1).

Mainly due to its economical potential, the lower Congo basin has been extensively studied since the 1960s. The continental margin architecture, as well as the stratigraphy of the proximal areas, has been rather well constrained by oil exploration seismic surveys and the presence of numerous oil wells and one ODP drilling cruise on the shelf and upper slope (e.g. Teisserenc and Villemin, 1989; Séranne et al., 1992; Rasmussen, 1996; Uenzelmann-Neben et al., 1997; Anderson et al., 2000; Lavier et al., 2000; Marton et al., 2000; Mougamba et al., 2000; Lucazeau et al., 2003). A few limited regional studies have provided some hints on the distal part of the fan and an idea of the size of the deep fan (Emery et al., 1975a; Uchupi, 1989, 1992).

However, the most recent and extensive study of the area was conducted from 1998 to 2005 within a partnership research project built by Ifremer and TOTAL, the ZaïAngo project, which involved a French multidisciplinary team including geologists, sedimentologists, geochemists, geotechnical engineers and geophysicists. 


\section{.2 The ZaïAngo project}

\section{.2.1 Origin and goals}

During the last 30 years, study of the continental margins has been one of the main objectives of Ifremer's research, while the TOTAL oil company has been increasingly focusing on deepoffshore energy resources. Following the two main discoveries of Nkossa and Girasol offshore Congo and Angola, Total decided to join forces with Ifremer in studying the ocean depths, forming a scientific and technical partnership. So at the end of 1997, Ifremer and TOTALFinaElf launched a five-year research programme devoted to studying the continental margin seaward of Gabon, Congo and Angola, with particular emphasis on exploring the huge submarine valley network carved in the ocean floor offshore the Congo river mouth. The ZaïAngo field program started in 1998 and was completed at the beginning of 2001 by the exploration, using a submersible, of the particularly active Congo abyssal valleys. This was immediately followed by the first BioZaire campaign. Over the three years between 1998 and 2001, a total of seven ZaïAngo cruises were carried out, using the full range of up-to-date oceanographic exploration equipment, from $500 \mathrm{~m}$ water depth down to $5000 \mathrm{~m}$ in a part of the Atlantic that had hitherto remained largely unexplored. The ZaïAngo project was intended particularly to study, at a regional scale, the recent Congo fan in order to acquire an integrated regional understanding of sedimentary processes controlling the distribution and the characteristics of the reservoirs, from the river mouth to the distal areas.

\section{.2.2 The ZaïAngo data set}

Two cruises, ZaïAngo 1 and 2, explored 200,000 km² in 1998 (Fig. 2). In 2000, the ZaïAngo project carried out five successive cruises (ZaïAngo-Sar, ZaïAngo-Car, ZaïAngo-OBS-SMT, ZaïAngo-Rov1 and 2) and scored a number of major technical firsts. The first significant efforts were made in the field of seismic surveying, with $4200 \mathrm{~km}$ of multi-channel HR (high resolution) seismic profiles in the deep offshore during ZaïAngo 1 and 2 cruises.

The ZaïAngo-Sar cruise aimed at defining ocean-bottom micro-topography using the SAR system (high-resolution side-scan sonar towed $100 \mathrm{~m}$ above the seafloor), with the emphasis on gaining a better understanding of current dynamics in the Congo submarine valley and achieving better images, at the water-sediment interface, of fluid-escape zones. The ZaïAngo-OBS-SMT cruise was devoted to the study of the deep structure of the continental margin, with the emphasis on obtaining images of the subsurface down to the underlying continental crust, i.e. at depths of fifteen to twenty kilometres below the surface of the sea. The cruise ZaïAngo-Car aimed at providing images of surface sediments, involved reconnaissance of the meandering Congo channel and of pockmarks - circular depressions from 20 to $1,000 \mathrm{~m}$ in diameter, marking the sites where cold-seep fluids emerge from deeper layers. A video camera was used for direct seafloor observation, providing the first indications that particular faunas were associated with cold seeps in the vicinity of the Congo Channel.

Lastly, ZaïAngo-ROV 1 and 2 cruises used the Victor 6000 remote-operated vehicle (ROV). During ZaïAngo-ROV 1, eight dives were made at the ocean floor and 24 piston cores were collected. Thanks to a series of geological cross-sections along the flanks of the present Congo channel, geologists obtained detailed acoustic images of the structure of submarine Congo channel-levee deposits. During ZaïAngo-ROV 2, Victor 6000 investigated various types of pockmarks. Measurements of chemical tracers (methane, manganese) were taken, mainly close to the ocean floor, in order to determine the nature and the origin of fluids discharged at the 
seawater-sediment interface. Core samples were also taken in order to analyse interstitial fluids within the sediments and other geotechnical parameters (mechanical behaviour of sediments, slope instability).

\section{.3 Geological history of the margin}

\section{.3.1 Structural and stratigraphic setting}

The Congo deep-sea fan is located on the Congo-Angolan margin (Fig. 1), which is a mature, passive continental margin resulting from the Early Cretaceous opening of the South Atlantic Ocean (130 Ma) (Jansen et al., 1985; Marton et al., 2000). The sedimentary series of the lower Congo basin shows three main units, which correlate with three tectonic phases: pre-rift continental deposits (Jurassic), syn-rift fluvio-lacustrine deposits and sag phase (Lower Cretaceous), and the post-rift unit with a large accumulation of salt (Middle Aptian) covered by thick marine successions (Albian to present).

The terrigenous sedimentary input to the Atlantic Ocean increased strongly during the Cenozoic because of (1) onland structural deformation and uplift, increasing bed-load transport in rivers, (2) the concomitant draining of the Congo River into the Atlantic Ocean, (3) the worldwide lowering of sea level during the later Cenozoic, and (4) a humid climate in the drainage area (Reyre, 1984; Droz et al., 1996). These factors resulted in the initiation of the huge Congo turbiditic sedimentation system first on the slope and then in the Lower Congo basin since Oligocene time (Brice et al., 1982), and the formation of the Congo deep-sea fan (Fig. 1).

Because of the instability of the salt layer, the sedimentary cover on the continental slope is affected by important syn- and post-sedimentary deformation due to gravity tectonics, which generated growth faults, salt sheets, diapir structures and compressional structures in response to substratum morphology of the basin and to the increase of sediment load. This structural style is similar to that observed on other continental margins with high depositional rates; for example the northern Gulf of Mexico (Winker, 1996), where salt diapirism is present, and the Niger Delta continental margin, where shale diapirism is active (Damuth, 1994). This structural style is a major issue in terms of controls on fluid escape on the continental slope.

\section{.3.2 The Congo deep-sea fan}

The maximum thickness of the Congo Tertiary deep-sea fan is estimated at about $5 \mathrm{~km}$, based on the interpretation of regional seismic profiles (Anderson et al., 2000; Cramez and Jackson, 2000; Marton et al., 2000). Oligocene and Miocene turbidite systems have been particularly studied by the oil industry, due to the discovery of oil and gas reservoirs in the Tertiary series. During the Miocene (24-5 Ma), the whole African continent has been affected by significant uplift, increasing the relief at the continental margin and the terrigenous sediment supply and inducing a progressive rearrangement of the watersheds. The discharge of the paleo-Congo river may have undergone a large-scale shift from south to north during the Miocene (Lavier et al., 2001), becoming the present Congo River. Only small rivers were feeding the Angolan margin during the Upper Miocene. Large Upper Miocene turbidite channels have been recognized in the Congo margin (to the north of the present Congo canyon) by Ferry et al. (2004). The initiation of the Congo canyon at its present location is estimated to date from the Miocene-Pliocene transition at approximately 5 Ma (Ferry et al., 2004).

Studies based on ZaïAngo data have provided a better understanding of the stratigraphy and evolution of the abyssal plain during the Tertiary, where the main fan depocenters are located 
(Anka and Seranne, 2004; Anka et al., in press). Séranne and Anka (2005) showed that the Tertiary turbidite series were largely controlled by important climatic changes and by the Miocene uplift of the African coastal plain.

The recent Congo fan extends from the Congo-Angola continental shelf downslope to abyssal depths (> $5100 \mathrm{~m}$ ) along a distance of $800 \mathrm{~km}$. Its surface area is estimated at $300,000 \mathrm{~km}^{2}$, similar to the areas of the Amazon fan. Data acquired during the ZaïAngo 1 and 2 surveys provided an almost complete view of the Quaternary architecture of the Congo Fan (Erreur ! Source du renvoi introuvable.3). Results are based on the combined analysis of multi-beam (EM12) and seismic-reflection data (high-resolution multichannel profiles). Bathymetry and acoustic imagery show the continuity of channel-levee systems, while seismic data were used to analyze facies, geometries and stratigraphic interrelations to reconstruct the architecture of the fan. Correlations with ODP Leg 175 indicate that the studied portion of the Congo fan started to form in the Upper Pleistocene (780 ka) and allow us to propose a tentative timing for the construction of the fan (Droz et al., 2003).

\section{.4 A brief overview of the Quaternary Congo fan}

\section{.4.1 Regional architecture of the fan}

The architecture of the fan results from the growth, avulsion and death of tens of submarine valleys bordered by thick muddy levees and feeding distal lobe units, which represent the three basic architectural elements of the fan (Fig. 3) representing 80-90\% of the sediment thickness imaged in seismic sections. Unconformable mass-transport deposits are less frequent, representing less than $10 \%$ of the total sediment.

More than 80 correlateable channel-levee systems were mapped, chronologically referenced, and numbered on the Congo Fan (Fig. 4). The stacking of channel-levee systems, in response to lateral shifts of the channels due to successive avulsions, defines the architecture of the fan (Droz et al., 2003). From the lower to the upper fan, the network of channels is hierarchically organized into progressively greater and more intricate sedimentary features. The channel-levee systems, grouped into several channel-levee complexes, appear to belong to three main successive fans that were named the Northern, Southern and Axial fans, from the oldest to the youngest (Fig. 4). Individual fans were fed by a unique source: the Congo Canyon; they appear as distinct basinward-opening triangular depocenters forming the Upper Quaternary Congo fan (Droz et al., 2003). The distribution of channel-levees is dominantly controlled by the available space, although a control by the climate and sea-level changes cannot be disregarded (Kolla, 2007; Marsset et al. in press).

The Northern Fan includes 23 channel-levee systems and its mean orientation is more or less the prolongation of the straight upper course of the canyon (ESE-WNW). The Southern Fan was surveyed along the upper $300 \mathrm{~km}$. It has a NNE-SSW mean orientation and includes 19 systems (Fig. 4). The Axial Fan developed in an approximate E-W direction, in the topographic low left between the two older depocentres and as the straight prolongation of the present-day lower portion of the canyon (Fig. 4). It includes 38 channel-levee systems, named A1 to A38 from the oldest to the youngest (Droz et al., 2003). 


\section{.4.2 Tentative timing for the construction of the northern, southern and axial fan}

A few key seismic reflectors were used to constrain the time of deposition of the northern, southern and axial fans, based on chronology from ODP Leg 175 drilling data on the Congo continental slope (Wefer et al. 1998). The Northern Fan is thus thought to have started developing at $780 \mathrm{ka}$. Its activity ceased around $540 \mathrm{ka}$, when the turbidite depocentre suddenly shifted to the Southern Fan, along the Angola escarpment. Lastly, the Southern Fan was abandoned, possibly at $210 \mathrm{ka}$, and the Axial Fan began to develop and is still currently active.

\subsection{Congo fan sediment sources}

The characterization of the sediment sources can help us to understand the present and very recent activity of the Congo turbidite system and the initiation of submarine flows able to flow all along the submarine Congo channel.

There are three main sources (Fig. 5):

- The Congo River with possible initiation of hyperpycnal flows or instabilities in the canyon head due to sediment overload (fine-grained sediments and organic debris).

- Longshore drift, which transported sandy sediments along the coast (northward), built the mouth bar of the Congo River Estuary and fed laterally the Congo canyon

- Canyon-flank instabilities, with reworked marine muddy deposits of canyon flanks and previous sedimentary accumulation.

The activity of the Congo turbidite system is directly linked to the behaviour of the Congo River (solid and liquid discharge, periodicity of flooding). This behaviour has changed over time, in relation to relative sea-level variations, tectonic episodes (inducing structural and morphological changes of the watershed) and climatic changes. It is difficult to estimate the time evolution of these parameters, but the characterisation of the present behaviour of the Congo River is easier and can help us to understand the present and very recent activity of the Congo canyon.

The Congo River is about $4700 \mathrm{~km}$ long and drains the Congo watershed (drainage area), which is $3.710^{6} \mathrm{~km}^{2}$ (Van Weering and Van Iperen, 1984). This watershed covers the entire Democratic Republic of the Congo and contains several large lakes or water bodies (e.g., Lake Tanganyika). The Congo River runs out across a series of relatively flat areas separated by waterfall segments, the last one being very close to the estuary.

The average flow (fluid discharge) of the Congo River is $42,800 \mathrm{~m}^{3} / \mathrm{s}$ (Kinga-Mouzeo, 1986); it is the second greatest in the world after the Amazon River $\left(200,000 \mathrm{~m}^{3} / \mathrm{s}\right)$. Fed by numerous tributaries located on both sides of equator, the annual hydrodynamic regime of the river is relatively constant. However, it shows seasonal cycles related to the time lag between wet seasons in the two hemispheres (Kinga-Mouzeo, 1986; Laraque et al., 1993b, a). The main lowwater stage occurs in July and August, corresponding to the drought in the southern hemisphere, and the main flood period in November and December, caused by the wet season in the northern hemisphere. A secondary low-water stage is observed in February and March during the northern hemisphere drought, and a secondary flood period in April and May brought on by the wet season in the southern hemisphere.

In comparison to other tropical rivers, the Congo River shows only moderate flooding, which is attenuated by the presence of numerous lakes (Jansen et al., 1985). The annual suspended discharge is low in comparison with the Amazon River. The Congo sediment discharge is 
estimated to be $55 \times 10^{6}$ tons/year (Wetzel, 1993), whereas the Amazon sediment discharge is around $900-1000 \times 10^{6}$ tons/year. This relatively low value is essentially the result of the low average elevation of the watershed and trapping of most of the alluvial deposits in lakes (BongoPassi, 1984).

The bedload discharge has not been estimated for the Congo River, but it can be significant during flooding. Thus, the present fluvial sedimentary input to the turbidite system is rather poorly known.

The downstream part of the Congo River (the last $150 \mathrm{~km}$ ) is divided into four main morphological areas (Fig. 5):

- Upstream from the estuary, the Congo River flows over numerous waterfalls and rapids and drops $150 \mathrm{~m}$ over less than $80 \mathrm{~km}$

- Over the next $50 \mathrm{~km}$, the valley morphology is relatively narrow ( $<1 \mathrm{~km})$ and the river is up to $150 \mathrm{~m}$ deep, being confined between high cliffs..

- Between the cities of Boma and Malela, the river path widens and shifts in multiple distributaries with shallow water depths $(6-7 \mathrm{~m})$, an area of sedimentation and of trapping of coarse sediments (sand and silt).

- $\quad$ The downstream part is characterised by the presence of the submarine canyon head (Heezen et al., 1964a), which penetrates up to $30 \mathrm{~km}$ into the river estuary. At the coastline, the water depth is 400-500 m (Shepard and Emery, 1973). The Congo River mouth is micro-tidal estuarine (tidal range is lower than $1.4 \mathrm{~m}$ and tidal currents are relatively low).

\section{.5 Present Congo fan morphology}

The morphology of the present seafloor was determined from EM12 bathymetric surveys acquired during the Guiness and ZaïAngo cruises (Droz et al., 1996, Savoye et al., 2000b). As shown by Babonneau et al. (2002), the general morphology of the margin exhibits three separate domains: the continental shelf, the continental slope and the abyssal plain.

\section{.5.1 Morphological study}

The shelf is limited downslope by the shelf break at $200 \mathrm{~m}$ water depth (black dashed line on figure 2). The shelf is about 65 to $80 \mathrm{~km}$ wide and it is deeply incised by the Congo canyon (Fig. 2).

The continental slope is divided into two separate domains: the upper slope and the lower slope (Figs. 2 and 6). The bathymetric gradient is about $2-3^{\circ}$ along the steepest part (upper slope). The upper slope is relatively smooth and regular down to $2000 \mathrm{~m}$ and locally affected by normal faults. The lower slope displays a more irregular morphology, as the sea floor is highly deformed by salt diapirism and compressional structures (salt domes and reverse faults). This compressional domain extends down to $3000 \mathrm{~m}$ water depth, and corresponds to the foot of the slope. This domain is particularly well developed on the Angolan margin (south of the canyon), where salt is more abundant (Fig. 2). The Congo canyon deeply incises the continental slope also in this lower part (Figs. 6 and 7). The canyon is marked by a pronounced northward deviation, induced by the active diapirism of the Angolan lower slope (Figs. 2 and 7).

The middle/lower Congo Fan extends from the base of the continental slope to the abyssal plain (Figs. 2 and 6) and has a very low gradient $\left(0.5^{\circ}\right)$. 
From the shelf to the abyssal plain, large deep-sea fans are composed of a succession of different architectural elements, which reflect the behaviour of turbidity currents across the oceanic domains. Across the shelf and the upper slope, sedimentary transport and erosional processes are dominant and induce incision and erosional features. In contrast, at the foot of the slope, depositional processes are more important and build sedimentary bodies such as channel-levee and lobe deposits. The present Congo Channel is continuous and clearly visible on the morphology, due to its deep incision. It extends as far as $750 \mathrm{~km}$ from the African coast as an apparently erosional feature, and ends in a relatively flat area that is likely a lobe deposit (Fig. 2). Figure 7 shows the channel shape evolution from the canyon area down to the distal lobe area.

\section{.5.2 The canyon}

Canyons typically correspond to the transit route for sediments from the continental domain (shelf) to the deep-marine domain. The Congo canyon is deeply incised, up to $1300 \mathrm{~m}$ and is a relatively wide feature (up to $12 \mathrm{~km}$ ). The canyon exhibits a V-shaped profile, relatively steep flanks and erosional and by-pass features such as chutes, gullies, slump scars and small tributary canyons. Most of the Congo canyon path shows well-developed terraces besides a small entrenched thalweg which is less than $2 \mathrm{~km}$ wide and $350 \mathrm{~m}$ deep.

As long as the canyon behaves as a sediment transit route, there is no net sedimentary accumulation within the canyon at a geological scale. Should sediment accumulate on canyon floor from hemipelagic fallout or from low-energy turbidity currents, this material will be removed by high-energy turbidity currents. When the turbidity current activity decreases, a canyon may fill progressively, but this is not the case of the Congo canyon today.

\section{.5.3 The channel-levee system}

Downslope from the canyon, channel-levee systems are mixed areas, where transit and depositional processes occur simultaneously. They generally develop beyond the base of slope and are one of the major architectural elements of large deep-sea fans. On the Congo fan, they are commonly several hundreds of kilometres long with a meandering path (Fig. 7). Babonneau (2002) distinguished the Upper fan valley at the transition between true canyon and the main channel-levee system, the upper channel-levee area and the lower channel-levee area (Fig. 7).

In seismic sections, an axial channel is bordered by levee deposits (Fig. 3). The channel is the path for turbidity currents to flow across the abyssal plain. Laterally away from the channel axis, levees form, consisting of lens shaped accumulations of overbank turbidites. They are dominantly composed of fine-grained turbidite sequences (silts and muds), supplied by overflows of the upper part of turbidity currents. Levees are present for a maximum channel relief (channel height) about $350 \mathrm{~m}$ with a lateral extent of as much as $30 \mathrm{~km}$ (Babonneau, 2002). The size of the channel-levee system (channel relief, levee thickness and levee extension) decreases downslope to the distal area, where the channel disappears and feeds distal lobes.

Turbidity currents are thus more confined in the upper part of the channel-levee system than in the distal part. As a consequence, channel axis accumulations are coarse-grained deposits (only sand and gravels), which are probably frequently reworked. Secondary architectural elements on Congo levees include large sediment waves (Migeon et al., 2004) that are related to the dynamics of overflowing turbidite currents. Two different overflow processes have been identified: flow stripping (Piper and Normark, 1983), corresponding to local overflows in meanders and overspill, which is continuous along the channel. 


\section{.5 .4 Lobes}

The term lobe is generally used to describe lobate accumulations at different scales and in different areas of fans. Channel-mouth lobes are located at the distal end of the channels: they are also called distal lobes or terminal lobes. They are not well known because of their distal location in large deep-sea fans (at water depths of more than $4000 \mathrm{~m}$ in most cases). They correspond to the most distal depositional areas in fans, where most turbidity currents die and lose the material held in suspension by turbulence.

\section{.5.5 Sedimentation along the present channel-levee and lobe}

The flow behaviour along the Congo channel can be inferred from the distribution and features of the deposits described along the present levee crest.

In the upper part of the channel-levee system, the silty-clayey deposits predominate (core KGC07, location Figure 8), indicating that levee relief $(\sim 250 \mathrm{~m})$ prevents spillover of silt and sand carried in the middle and lower parts of channelised flows (Fig. 9). Despite the meandering pattern of the channel that favoured the action of centrifugal forces and flow stripping, flow thickness is still low in comparison with channel relief. Uncommon, thin, clayey-silty layers suggest rare overflows from thicker billows carrying coarser, suspended particles.

In the middle part of the channel-levee system (core KZAI05), as channel relief decreases to 120 $\mathrm{m}$, individual turbidite sedimentary sequences (beds) exhibit 5-10 silty laminae (Gervais et al. 2001). The number of overflows is still limited, but each overflow transports greater volumes of coarse, suspended particles. In the lower channel-levee, the channel relief becomes less than 60 $\mathrm{m}$. Sequences are coarser and turbidite beds are numerous. The resulting increase in sedimentation rate means that the upper $6 \mathrm{~m}$ of core KZR12 should be compared to less than one metre of core KZAI05.

Along the entire channel path, flow thickness is inferred to decrease only slightly as fine-grained sediments are dispersed by overflow on levees and as the flow stretches along the channel. Water entrainment is low owing to the subcritical condition of the currents, which are necessary to maintain the flow over a long pathway (Pirmez and Imran, 2003). However, currents remain thick enough to overflow along the channel path as the channel relief continuously decreases downslope. With the loss of fine-grained suspended sediments by overflow, mean flow concentration increases downslope. Overflows become relatively continuous on the levees and carry coarser particles. Because individual turbidite deposits are clearly identified in the cores, it is possible to estimate the average frequency of depositional events on the levees. In core KZAI14, the number of turbidites compared to the historical timescale suggests that the frequency of overbank deposition was constant over the last 5000 years, with about one overbank deposit every 45-55 years. This is lower than the frequency estimated for the Amazon fan, with about one overbank deposit every 3-8 years during low-stand periods (Piper and Deptuck 1997), but low-stand activity of the Congo system is not recorded in the cores. This frequency is also low in comparison with the frequency of cable breaks, i.e. of generated gravity flows, reported by Heezen et al. (1964) in the canyon axis during the 20th century (see below). This means that either most of the gravity flows died out before reaching the middle and downstream part of the channel-levee system, or most of them were too thin $(<100 \mathrm{~m})$ to overspill the levees. 


\section{.6 An active deep-sea fan system in high sea-level conditions}

An important particularity of the Congo turbidite system is the continuous turbidite activity during the last sea-level rise and high sea-level period, due to the permanent connection between the River mouth and the canyon head. The activity of the Congo turbidite system is directly linked to the behaviour of the Congo River (solid and liquid discharge, periodicity of flooding). This behaviour has most probably changed over time, in relation to relative seal-level variations, tectonic episodes (inducing structural and morphological changes of the watershed) and climatic changes.

\section{.6.1 Several lines of evidence of very recent turbidity current activity}

\section{The first evidence: historical submarine cable breaks}

By documenting submarine-cable breaks near the Congo canyon between 500 and $2300 \mathrm{~m}$ water depth, Heezen et al. (1964) attributed the present-day activity to turbidity currents related to river flood periods. The Sao Tome-Luanda (Angola) Cable, originally laid in 1886 and abandoned in 1937, failed 30 times near the axis of the Congo Canyon. The first route selected from Buchanan's survey, at around $11^{\circ} 30^{\prime} \mathrm{E}$, was used from 1886 to 1893, during which time the cable failed five times. In 1893 it was decided to divert the cable into deeper water ( $5^{\circ} 30^{\prime} \mathrm{S}, 10^{\circ} 30^{\prime}$ E) where failures are in general less common. This second route crossed the canyon in much deeper water $(2000 \mathrm{~m})$, but in this location the cable suffered eight breaks between 1893 and 1897. Each of the eight failures was a tension break and in all cases the section of cable near the axis of the canyon was buried and abandoned. Then, the cable was diverted into the river mouth where it failed 15 times until 1937. The cable engineers recognized that the cable failures were related to the transport of sediment down the canyon from the Congo River. A mean recurrence interval of about 60 breaks per century has been estimated.

\section{Observation of a submarine avalanche during ZaïAngo cruise survey}

During the last ZaïAngo-Rov cruise in December 2000, the last ROV dive, carried out in the canyon at $2600 \mathrm{~m}$ water depth, was a unusual experiment. On arrival at the bottom, all ROV monitors were absolutely black, whereas all the projectors were lit. Even the arm and basket of the ROV could not be seen. The ROV engineers even believed for a moment that the ROV had broken down. At $20 \mathrm{~m}$ above the canyon floor, the gleam of the projectors started to diffuse and a reddish image appeared on the screens. Finally, starting $100 \mathrm{~m}$ above the canyon floor, the visibility started to return with an aspect "falls of snow" still very marked for a further $75 \mathrm{~m}$ of elevation. The ROV was probably in the very dense basal part of an underwater avalanche flowing down the canyon. Later during the dive, the ROV went back to the canyon floor and as the acoustic ROV positioning device was still working, ROV engine was stopped and the ROV track was followed over a period of $20 \mathrm{~min}$. The ROV was moving northwards at an average speed of 4 knots following the canyon thalweg direction. For the first time, Victor was diving in the middle of a turbidity current.

\section{Ifremer mooring experiments along the present submarine Congo valley}

In January 2001, a mooring was first deployed in the present Congo turbidite channel at $4000 \mathrm{~m}$ water depth (site D'), during the BioZaire cruises (Kripounoff et al., 2003). A large turbidity current was detected in the Congo channel in March 2001, three months after the ROV dove into 
a submarine avalanche within the canyon area. Current meters, a turbidimeter and a sediment trap deployed on the mooring were damaged but were able to record the signature of an energetic current (see XXXXX, 2009). This experiment was pursued during four years within the BioZaire project and recorded 2 periods of major turbidity events, which surely flowed down all the Congo submarine valley with a very high energy (underestimated by our measurements). For example, a turbidity current flow velocity of $8.4 \mathrm{~km} / \mathrm{h}$ was estimated between the depths of 3000 and 4000 $\mathrm{m}$, over a distance of $160 \mathrm{~km}$.

\section{Recent erosional activity observed into the distal lobes}

The ZaïAngo survey provides a complete bathymetric map of the Congo turbidite channel from the canyon head to the distal lobe area. As it is highly meandering, it has an unfolded length of about $1200 \mathrm{~km}$. The channel is bordered in its distal part by thin levees and suddenly disappears at a water depth of about $4900 \mathrm{~m}$ (Fig. 2). Without sonar imaging, the channel-mouth lobes would have been difficult to detect as they are extremely discreet morphologically. The backscatter EM12 image shows that the Congo channel runs into a series of 4 sub-lobes clustered in a grape-like prograding downstream organization (Savoye et al., 2000).

We used the SAR deep-tow side-scan sonar to collect detailed images of the seafloor in the channel-mouth lobe area at about $5000 \mathrm{~m}$ water depth. The sonar was towed at $100 \mathrm{~m}$ above the sea-floor and used a $200 \mathrm{kHz}$ mean frequency. The images collected in the area are very rich and contrasted. They show that the microtopography of the seafloor is very heterogeneous and highly disturbed. Many erosional and bedform structures were observed in the feeding lobe channel of the most recent lobe, such as furrows, rolled blocks, and scours (Bonnel, 2005) (Fig. 10), indicating that even if the lobes are at $5000 \mathrm{~m}$ water-depth and at a distance of $750 \mathrm{~km}$ from the head of the canyon, some turbidity currents are powerful enough to rework and erode the seafloor.

\section{.6.2 AMS radiocarbon ages and sediment accumulation rates}

The continuous activity of the Congo fan is also recorded in deep-sea sedimentation. Cores taken along the present Congo turbidite system (channel floor, levees and lobes) show high sedimentation rates during the Holocene and confirm the turbidity current activity during the Holocene. A few tens of sediment cores were collected from the Congo canyon and deep-sea fan, during the ZaïAngo cruises and a former Ifremer cruise. They underwent sedimentological studies and we performed dating studies on 16 cores. Published AMS radiocarbon dating from two other cores (Jansen et al., 1984) were also used. Dates are given in calibrated ages Before Present. The core locations are shown in Figure 8. The water depth of the cored sites ranges from $816 \mathrm{~m}$ to $4900 \mathrm{~m}$. The core lengths range from less than 1 to $18 \mathrm{~m}$. The samples were collected from the canyon shoulders, from terraces inside the canyon (Babonneau et al., 2004), from the levees (Gervais et al. 2001; Migeon et al. 2004), in the channel and from the distal lobes (Bonnel et al. 2001) (Figure 8).

To determine the age, time intervals and accumulation rates, the investigations focused on the stratigraphy of siliceous microfossils and calcareous nannoplankton, radiocarbon dating and the determination of excess ${ }^{210} \mathrm{~Pb}$. Most of the AMS radiocarbon dating was performed on terrestrial plant debris, generally collected in silt layers at the base of turbidite sequences. Some dating was performed on marine carbonate shell debris and on foraminifera shells. 
In the present channel (cores taken in the channel floor), average accumulation rates are 57.5 $\mathrm{cm} . \mathrm{ka}^{-1}$ in core KZAI-06 and $23.6 \mathrm{~cm} \cdot \mathrm{ka}^{-1}$ in core KZAI-15. These ages suggest a maximum age of $\sim 27 \mathrm{ka}$ for the sediment retrieved in the present channel. The age found at the top of core KZAI-06 shows that the channel collected significant turbidite deposits until the 17th century.

Accumulation rates along the canyon shoulders are the lowest and are negatively correlated to the channel depth. This suggests a probable contribution from dilute, turbid plumes from the canyon. On a terrace within the lower Congo Canyon (KZR-23), the accumulation rates are very high $\left(135.5 \mathrm{~cm} \cdot \mathrm{ka}^{-1}\right)$ despite the distance from the Congo plume and the significant relative depth of the channel $(380 \mathrm{~m})$. This reflects a confined environment, between the canyon walls, preventing the dispersion of the turbidite plume. The base of the core (from $15.5 \mathrm{mbsf}$ ) recorded turbidite beds with a silty base prior to $12.5 \mathrm{ka}$ (calibrated age) (Babonneau et al., 2002a), evidence for a significant turbidite spillover from the canyon.

From upstream to downstream along the channel-levee system, the maximum ages in the cores range from $12.5 \mathrm{ka}$ (T78-30) (Jansen, 1985), $10.5 \mathrm{ka}$ (KZAI-05), $3.7 \mathrm{ka}$ (KZAI-13) to $1.7 \mathrm{ka}$ (KZR-12). Despite discrepancies in the length of the cores, the ages tend to be younger downstream, reflecting an increase of the accumulation rates. These are negatively correlated to the channel depth and positively correlated to the distance along the channel (Figs. 11 and 12). The accumulation rates within the sediment cores show a very strong variability and reach up to $28 \mathrm{~m} . \mathrm{ka}^{-1}$. Indeed, the period of highest accumulation rate is very short, about 150 years, for a thickness of $\sim 4 \mathrm{~m}$. Most of the accumulation rates range between about $10 \mathrm{~cm} \cdot \mathrm{ka}^{-1}$ and $5 \mathrm{~m} . \mathrm{ka}^{-1}$. They are of the same order as those calculated on the Amazon fan (Showers et al., 1997), except that the Amazon levees were starved in the Holocene, while abundant turbidite deposits accumulated on the recent Congo levees. The average accumulation rates are much higher than those in the adjacent hemipelagic facies (Jansen et al., 1984; Dennielou, 2003) and demonstrate a significant supply of turbidite sediments during the Late Holocene. The deposition of turbidite sequences during the Late Holocene is restricted to a narrow strip (about $10 \mathrm{~km}$ ) on both sides of the present channel and to the $70 \mathrm{~km}$ long, $30 \mathrm{~km}$ wide channel-mouth lobe area (Babonneau, 2002).

${ }^{210} \mathrm{~Pb}$ excess was measured at two sites on the levee and eight sites on channel-mouth lobes and helped to estimate sediment accumulation rates in the last century. The signal always shows a strong variability, which is believed to be related to the discontinuous nature of the turbiditic supply and to the reworked nature of turbiditic sediments.

In distal lobes, the accumulation for the last century has been estimated between $56 \mathrm{~cm}$ (KZAI07) and $121 \mathrm{~cm}$ (KZAI-12). These high accumulation rates show that both lobes collected voluminous sediments in the last century. Over the past century, the levee recorded high sedimentation rates, but 3 times lower, with no recorded major coarse turbidite event. This suggests that most turbidity currents were relatively thin and unable to significantly overspill the levee

The channel-levee morphology and the turbidity current mutually interact. For instance, the accumulation rates along the present Congo levee are strongly controlled by the channel depth (Fig. 12) even though they are not strictly correlated to it. A substantial increase of the accumulation rates in the lower channel-levee, between km 712 (KZAI-05) and 855 (KZAI-13 and KZAI-14) does not correspond to any significant variation in water depth nor in channel slope (Babonneau, 2002). On the other hand, it does correspond to a variation in the channel sinuosity, as well as to the beginning of a continuous decrease in the channel relief (or channel height) from about $70 \mathrm{~m}$ (at $\mathrm{km} \mathrm{850)}$ to zero at the channel-lobe transition (Babonneau et al., 
2002b). These features are interpreted as major variations in overflow processes, related to the volume of turbidity currents, and we suggest that the channel depths at which they occur, between $\sim 135 \mathrm{~m}$ and $\sim 95 \mathrm{~m}$, represent the average thickness of the turbidity currents flowing down the channel. This transitional area along channel-levee systems is known for other submarine channel-levee (Skene et al., 2002). Upstream, at higher channel depths, turbidity current overflows are rare and/or diluted. Downstream, at lower channel depths, turbidity current overflows are common and concentrated. The transition between low and high accumulation rates along the levee is constrained by only two points $143 \mathrm{~km}$ apart and, therefore, may occur over a shorter distance. For channel depths between $\sim 135 \mathrm{~m}$ and $260 \mathrm{~m}$, lower accumulation rates on the levee are associated with a change in turbidite facies. Where the channel depth is more than $\sim 260 \mathrm{~m}$, coarse turbidite spillovers never occurred in the last $\sim 10 \mathrm{ky} \mathrm{BP}$, suggesting that it represents the maximum thickness for concentrated Holocene turbidity currents inside the Congo channel. No evidence of turbidite overflow is found on the shoulders of the upper-fan valley for the last $10 \mathrm{ky}$ (cores KZAI-01, T78-27). Nevertheless, the high accumulation rates in the hemipelagic facies, two to three times higher than those expected accordingly to the distance from the coast (Dennielou, 2003; Jansen et al., 1984), demonstrate a strong depositional influence of the Congo River, either from the surface river plume, or from the canyon.

Our dating confirms the strong control of the channel-levee morphology on the turbidite overflow processes, in agreement with the model of channel-levee development proposed by Skene et al, (2002) and the activity of the Congo deep-sea fan during the present sea level high. During the last century, ${ }^{210} \mathrm{~Pb}$ excess data show that more than one meter of turbidite sequences was deposited on the distal levee and on the channel-mouth lobe area, while the accumulation estimated by the radiocarbon dating was much lower for the Late Holocene. Although the dating control is limited, we interpret the higher accumulation recorded for the last century as a true change in the amount of sediment supplied to the channel-levee and lobe. So far, we do not have an explanation for this, but one could suggest that the anthropogenic activity in the Gulf of Guinea and along the Congo River in the last century may have enhanced the sediment supply to the Congo deep-sea fan.

\section{.7 Present sediment supply from the canyon to deep water: a discussion}

Heezen et al. (1964) found correlations between submarine cable breaks (across the canyon) and the main floods of the Congo River. They established a direct relation between gravity events and the hydraulic regime of the river. However, different types of feeding process can be considered: such as direct canyon feeding by hyperpycnal currents generated by floods, or gravity currents generated at the canyon head by sediment overload and failure. On the other hand, lateral feeding by alongshore currents is attested by the observation of sharply incised chutes on the canyon walls, both from the southern shelf (particularly in the inner shelf) or from the northern shelf (particularly in the outer shelf).

\section{.7.1 Possible generation of hyperpycnal flows}

Measurements acquired during the normal regime of the river indicate that the sediment load in suspension is very low. The fresh water density remains lower than the marine water density. Mulder and Syvitski (1995) thought the Congo River was probably incapable of generating hyperpycnal flows. However, the true suspension-load and bed-load transported during flooding are not known. Moreover, recent works concerning the generation of hyperpycnal flows have 
shown that the critical concentration for hyperpycnal flow initiation could be significantly reduced, considering estuarine mixing characteristics (Felix et al., 2006). Thus, the generation of rare and short duration hyperpycnal flows inside the Congo Canyon during flooding might be possible.

\section{.7.2 Sediment overload at the canyon head}

The initiation of turbidity currents may be most probably due to punctuated slide events. Large accumulations of sediments are present in the estuary (for example the prograding sand bars). Especially during flooding, the flow volume increases and could carry large sediment accumulation near the canyon head. The sudden sediment overload could generate failures of the prograding sandy mouth, as proposed by Christian et al. (1998) on the Fraser River or by Syvitski and Hein (1991) in Iterbilung Fjord.

\section{.7.3 Longshore currents}

A lateral feeding process could occur. At the south of Equator, the African coast is affected by a northward longshore current, capable of transporting large volumes of sediments. It is responsible for the large southern mouth bars of the Congo estuary (Fig. 5). Small tributary thalweg of the Congo Canyon are directly located in the prolongation of the mouth bar and indicate a possible secondary sediment source of gravity current. Heezen et al. (1964) demonstrated the important contribution of the mouth bar, observing several cable breaks in these distributary thalwegs. Incoming swell could create rip currents that transport sediment off the mouth bar, that directly feed the tributary canyons, as demonstrated by Fukushima et al. (1985) and Normark and Piper (1991) in Scripps submarine canyon.

However, it is difficult to discriminate the canyon feeding processes as no direct observations or in situ measurements have been acquired in the canyon head (or in the river estuary) during flooding. Also no current velocities have been measured on the inner shelf close to the canyon head or on the outer shelf close to the shelf break.

As the canyon head is directly connected to the river estuary, it permits the activity of the turbidity currents during the present high-stand sealevel (proved by cable breaks, cores comprising Holocene turbiditic sediments and direct observations). Even though the precise initiating process for turbidity currents is uncertain, this morphology explains why the Congo deep-sea fan was active through the entire Holocene and why turbidite deposits were recorded up to the last century on the lower channel-levee and distal lobes.

\section{.8 Geological setting of the different Biozaïre sites}

Based on our study, we can precisely describe the geological setting of each BioZaire site (Fig. 13).

\subsection{Sites ZA and ZB}

These sites are located outside the Quaternary Congo fan on upper slope offshore Angola, in an area of huge oil discoveries in the mid 90's. These discoveries are located in ancient Congo fan paleo-channels, which are now deeply buried by hemipelagic sediment. This slope area is highly deformed by several tectonic processes. The ZA site is close to salt diapirs and ZB, which is higher on the slope is located in area of growth faults, which deeply affect the sedimentary column. 


\section{.8 .2 Site ZC}

Site ZC is located downslope from ZA and ZB at the base of the Angola slope. The local slope is very low. It is also largely outside the part of the Congo fan which is active to-day (more than $180 \mathrm{~km}$ from the active channel). However it is located in the area where the Congo fan built between - $460 \mathrm{ka}$ and $-210 \mathrm{ka}$. Below a 30-m-thick hemipelagic cover lie ancient buried paleochannels and levees. We expect that there is no major geological process active in the area.

\section{.8.3 Site Tete}

Site Tete is located in the middle part of the Congo canyon, which is mainly a by-pass zone. Most turbidity currents flowing down the Congo channel should flow across this area. In this area, an incised and narrow thalweg bordered on each side by several terraces marks the active path of turbidity currents. In this area, canyon flank instabilities are observed locally and might feed the canyon occasionally.

\section{.8 .4 Site Regab}

Site Regab was discovered in 1998 during the first ZaïAngo cruise. It is located in a giant pockmark, i.e. a fluid escape feature, which is marked on the sea-floor backscatter image by an amplitude anomaly. Several anomalies like Regab are observed in the area. Fluids ascend through the sedimentary column creating a chimney, which originates at the top of a former and buried Congo paleochannel. The Regab pockmark is located just at the border of the present Congo levee, i.e. in an area where turbidity current overflows coming from the channel are expected to be very rare and thin. There was also a BioZaire mooring site in the present Congo channel at the south of Regab. This part of the channel is a by-pass zone and most turbidity currents should be confined within the channel section.

\section{.8.5 Sites ZD and ZD'}

Site ZD' is located at about $4000 \mathrm{~m}$ water depth within the active Congo channel, downslope from the Regab area. Site D is located south of ZD', outside the present Congo levee. Both sites are upslope from the point where we observed a sudden increase of sedimentation rates in levee deposits. Thus these sites are in part of the channel where overflow processes are rarer and less energetic than farther down channel.

\section{.8.6 Site lobe}

The lobe site corresponds to the present channel-mouth lobe area, an area that can be reached by all high energy turbidity currents flowing down the Congo canyon. It is at about $5000 \mathrm{~m}$ water depth and at a direct distance of $750 \mathrm{~km}$ from the coast (1250 km following the meandering Congo valley).

\section{.9 Conclusions}

The geological study of the Congo deep-sea fan, conducted by Ifremer, TOTAL and other partners, took place between 1998 and 2003. The results help to define the geological setting of the BioZaire studies and to enhance some particularities of the Congo submarine area.

(1) The BioZaire sites are mostly inside one of the main active deep-sea fans on the Earth's surface. The present Congo submarine valley ends at more than $750 \mathrm{~km}$ from the coast in $5000 \mathrm{~m}$ water depth. 
(2) The activity of the Congo fan, which is unusual compared to other known deep-sea fans of the same size - Amazon, Nile, Mississippi are inactive to-day - is explained by the direct connection of the Congo estuary and the head of the Congo canyon.

(3) The deposition of turbidite sequences during the Late Holocene $(<10 \mathrm{ka})$ is restricted to a narrow strip (about $10 \mathrm{~km}$ ) on both sides of the present Congo channel and to a $70 \mathrm{~km}$ long, $30 \mathrm{~km}$ wide channel-mouth lobe area.

(4) During the last $10 \mathrm{ka}$, the maximum thickness of the turbidity currents in the Lower Canyon was about $260 \mathrm{~m}$ and was between 135 and $95 \mathrm{~m}$ at $4500 \mathrm{~m}$ water depth.

(5) The present distal lobes, initiated after the last major channel avulsion, are Holocene in age and started to build up between 6.7 and $5.1 \mathrm{ka}$.

(6) The distal lobe accumulated turbidite deposits during the last century.

\section{Acknowledgments}

This paper is the result of the ZaïAngo Project, initiated jointly by IFREMER and TOTAL. We particularly thank TOTAL for the financial support of this research program. The authors also thank the two reviewers: M. Séranne and D.J.W. Piper for their comments and suggestions that significantly improved the paper.

This paper is the last one submitted by Bruno Savoye before his premature death. NB and BD made the final revision. Bruno's death is an enormous loss for marine geosciences but also for his family, friends, colleagues and students. Our sympathy go to Babette, his wife, and to Charlotte and Marion, his daughters. 


\section{$\underline{\text { List of tables }}$}

Table 1. Conventional AMS radiocarbon ages, calibrated ages and accumulation rates in cores from the Congo channel-levee and lobe. Lyon: dates from Université Claude-Bernard Lyon 1, LLNL: dates from Lawrence Livermore National Laboratory, NIOZ: dates courtesy of Fred Jansen. Calibration of radiocarbon ages is after Stuiver et al. (1998) for radiocarbon ages up to 20,265 a BP, and with the Glacial polynomial of Bard et al. (1998) for radiocarbon ages between 20,265 a BP and 36,000 a BP (indicated with asterisk)

\section{List of figures}

Figure 1 - Location map of the Congo sedimentary system

Figure 2 - 3D View of the bathymetric map acquired during ZaïAngo cruises (EM12 data). The Congo canyon deeply incises the shelf and the continental slope, and feeds the fan through numerous meandering channels (visible on the fan surface).

Figure 3 - Schematic cross-section and general overview of a single channel-levee system. Light green colour represents levee deposits resulting from overflows of turbidity currents flowing down the channel. Dark green colour corresponds to coarser channel deposits. Channel mouth lobes are deposited at the distal end of the channel

Figure 4. (A)Map of the 80 paleochannels identified on the fan surface, grouped into 3 main fans: Northern, Southern and Axial (Droz et al., 2003). Channels are traced and chronologically numbered N1 to N23, S1 to S19, A1 to A38, from oldest (N1) to youngest (A38); (B) relative chronology of the three main fans, illustrated by seismic profiles Z2-25 and Z2-44 across the upper part of the Congo deep-sea fan (Location in figure 4).

Figure 5. (A) General map showing the connection between the Congo River estuary and the Congo canyon; (B) the detailed morphology of the Congo estuary (after Moguedet, 1988)

Figure 6. Longitudinal depth profiles along the present Congo Canyon/Channel. The depth profile along the channel floor corresponds to smoothed EM12 data (Babonneau et al., 2002)

Figure 7. Channel morphology evolution of the morphology from canyon to distal lobes (Babonneau et al., 2002).

Figure 8. Location of Kullenberg cores and ROV dives collected along the Congo channel-levee system; in yellow: the present active meandering channel; in green: its associated levees; and in brown: the channel-mouth lobe area. (after Babonneau, 2002).

Figure 9. Cores transect along the crest of the recent Congo levee, showing the overall sediment grain size evolution along the channel, with higher sedimentation rates and coarser material deposited in the distal part of the system. 
Figure 10. SAR sonar image showing erosional features and blocks at the present surface of the active lobe at $5000 \mathrm{~m}$ water depth.

Figure 11. 3D View of the ZaïAngo sonar mosaic, showing the present Congo canyon and channel and the accumulation rates calculated with sediment dates. In yellow sites of hemipelagic sedimentation, in black,sites of turbidite sedimentation

Figure 12. Average sediment accumulation rates at the top of the present levee and present channel depth versus the distance along the present channel. Accumulation rate in terrace ZR-23 is very high: $135 \mathrm{~cm} / \mathrm{ky}$, although it is measured entirely in hemipelagic sediments

Figure 13. Location of BioZaire sites on a general bathymetric map 


\section{References}

Anderson, J.E., Cartwright, J., Drysdall, S.J. and Vivian, N. 2000. Controls on turbidite sand deposition during gravity-driven extension of a passive margin: examples from Miocene sediments in Block 4, Angola. Marine and Petroleum Geology, 17: 1165-1203.

Anka, Z. and Séranne, M. 2004. Reconnaissance study of the ancient Zaire (Congo) deep-sea fan. (ZaiAngo Project). Marine Geology, 209: 223-244.

Anka, Z., Séranne, M., Lopez, M., Scheck-Wenderoth, M. and Savoye, B. The long-term evolution of the Congo deep-sea fan: A basin-wide view of the interaction between a giant submarine fan and a mature passive margin (ZaiAngo project). Tectonophysics, In Press, Corrected Proof.

Babonneau, N. 2002. Mode de fonctionnement d'un chenal turbiditique méandriforme: Cas du Système Turbiditique actuel du Zaïre, Université Bordeaux I, Bordeaux, 308 pp.

Babonneau, N., Savoye, B., Cremer, M. and Bez, M. 2002. Processes and Sedimentary Architecture along the Present Zaire Turbidite Channel (ZAIANGO Project). In: AAPG Annual Meeting, Houston.

Babonneau, N., Savoye, B., Cremer, M. and Bez, M. 2004. Multiple terraces within the deep incised Zaire canyon: are they confined levees? In: Turbidite Sedimentation in Confined Systems (Eds S.A. Lomas and P. Joseph), Special Publication, pp. 91-114. Geological Society of London.

Bard, E., Arnold, M., Hamelin, B., Tisnerat-Laborde, N., and Cabioch, G. (1998). Radiocarbon calibration by means of mass spectrometric $230 \mathrm{Th} / 234 \mathrm{U}$ and $14 \mathrm{C}$ ages of corals. An updated data base including samples from Barbados, Mururoa and Tahiti. Radiocarbon 40, 1085-1092.

Bonnel, C., 2005. Mise en place des lobes distaux dans les systèmes turbiditiques actuels: Analyse comparée des systèmes du Zaïre,Var et Rhône. PhD Thesis, Université Bordeaux 1,314 pp.

Bongo-Passi, G. 1984. Contribution à l'étude lithostratigraphique, minéralogique et géochimique du delta sous-marin profond du fleuve Congo, Université de Toulouse, 215 pp.

Bouma, A.H. 1962. Sedimentology of some flysch deposits: a graphic approach to facies interpretation. Elsevier, Amsterdam, 168 pp.

Brice, S.E., Cochran, M.D., Pardo, G. and Edwards, A.D. 1982. Tectonics and Sedimentation of the South Atlantic Rift Sequence: Cabinda, Angola. In: Studies in Continental Margin Geology (Ed W.C. Drake), 34, pp. 5-18. AAPG Memoir.

Christian, H.A., Mosher, D.C., Barrie, J.V., Hunter, J.A. and Luternauer, J.L. 1998. Seabed slope instabilitiy on the Fraser River delta. In: Geology and Natural Hazards of the Fraser River delta (Eds J.J. Clague, J.L. Luternauer and D.C. Mosher), pp. 525. Geological Survey of Canada Bulletin.

Cramez, C. and Jackson, M.P.A. 2000. Superposed deformation straddling the continentaloceanic transition in deep-water Angola. Marine and Petroleum Geology, 17: 1095-1109.

Damuth, J.E. 1994. Neogene gravity tectonics and depositional processes on the deep Niger Delta 
continental margin. Marine and Petroleum Geology, 11: 320-346.

Dennielou, B. 2002. Rapport Final ZaïAngo: Ages et taux d'accumulation du deep-sea fan du Zaïre, synthèse des éléments de stratigraphie, IFREMER, Brest.

Droz, L., Marsset, T., Ondreas, H., Lopez, M., Savoye, B. and Spy-Anderson, F.L. 2003. Architecture of an active mud-rich turbidite system: The Zaire Fan (Congo-Angola margin, southeast Atlantic). Results from ZAIANGO 1 and 2 cruises. AAPG Bulletin, 87: 11451168.

Emery, K.O., Uchupi, E., Phillips, J., Bowin, C.O. and Mascle, J. 1975. Continental margin off western Africa; Angola to Sierra Leone. AAPG Bulletin, 59: 2209-2265.

Felix, M., Peakall, J. and McCaffrey, W.D. 2006. Relative Importance of Processes That Govern the Generation of Particulate Hyperpycnal Flows. Journal of Sedimentary Research, 76: 382.

Ferry, J.-N., Babonneau, N., Mulder, T., Parize, O. and Raillard, S. 2004. Morphogenesis of Congo submarine canyon and valley: implications about the theories of the canyons formation. Geodynamica Acta, 17: 241-251.

Fukushima, Y., Parker, G. and Pantin, H.M. 1985. Prediction of ignitive turbidity currents in Scripps submarine canyon. Marine Geology, 67: 55-81.

Gervais, A., Mulder, T., Savoye, B., Migeon, S., Cremer, M., 2001. Recent processes of levee formation on the Zaire deep-sea fan. C.R. Acad. Sci. Series IIA 332, 371-378.

Heezen, B.C., Menzies, R.J., Schneider, E.D., Ewing, W.M. and Granelli, N.C.L. 1964. Congo Submarine Canyon. AAPG Bulletin, 48: 1126-1149.

Jansen, J.H.F. (Ed), 1984. Quaternary geology and oceanography of the Zaire deep-sea fan and adjacent Atlantic. (Ed J.W. De Blok), Netherlands Journal of Sea Research, 17 (2-4), 145$441 \mathrm{pp}$.

Jansen, J.H.F., Van Weering, T.C.E., Gieles, R. and Van Ipresen, J. 1985. Middle and late Quaternary oceanography and climatology of the Zaire-Congo fan and the adjacent eastern Angola Basin. Netherlands Journal of sea Research, 17: 201-249.

Kinga-Mouzeo 1986. Transport particullaire actuel du fleuve Congo et de quelques affluents; enregistrement quaternaire dans l'éventail détritique profond (sédimentologie, minéralogie et géochimie), Univ. de Perpignan, 251 pp.

Kolla, V., 2007. A review of sinuous channel avulsion patterns in some major deep-sea fans and factors controlling them. Mar. Pet. Geol. 24, 450-469.

Kripounoff, A., Vangriesheim, A., Savoye, B., Dennielou, B. and Babonneau, N. 2003. Direct observation of intense turbidity activity in the Zaire submarine Valley by $4000 \mathrm{~m}$ depth. Marine Geology, 194: 151-158.

Laraque, A., Mahé, G., Orange, D. and Marieu, B. 2001. Spaciotemporal variations in hydrological regimes within Cantral Africa during the XXth Century. Journal of Hydrology, 245: 104-117.

Lavier, L.L., Steckler, M.S. and Brigaud, F. 2001. Climatic and tectonic control on the Cenozoic evolution of the West African margin. Marine Geology, 178: 63-80. 
Lucazeau, F., Brigaud, F. and Leturny, P. 2003. ynamic interactions between the Gulf of Guinea passive margin and the Congo River drainage basin: 1. Morphology and mass balance. J. Geophys. Res., 108.

Marsset, T., Droz, L., Dennielou, B., Pichon, E., in press. Cycles in the architecture of the Quaternary Zaire turbidite system: a possible link with climate. In: B. Kneller (Editor), SEPM special publication.

Marton, L.G., Tari, G.C. and Lehmann, C.T. 2000. Evolution of the Angola passive Margin, West Africa, with Emphasis on Post-Salt Structural Styles. In: Atlantic Rifts and Continental Margins (Eds W. Moriak and M. Talwani), pp. 129-149. American Geophysical Union, Washington, DC.

Migeon, S., Savoye, B., Babonneau, N. and Spy-Anderson, F.L. 2004. Processes of sedimentwaves construction along the present Zaire deep-sea meandering channel: Role of meanders and flow stripping. Journal of Sedimentary Research, 74: 580-598.

Moguedet, G. 1988. Les relations entre le fleuve Congo et le sédimentation récente sur la marge continentale entre l'embouchure et le Sud Gabon: étude hydrologique, sédimentologique et géochimique. Thèse d'état, Univ. Angers, Angers, 187 pp.

Mulder, T. and Syvitski, J.P.M. 1996. Climatic and morphologic relationships of rivers: implications of sea-level fluctuations on river loads. The Journal of Geology, 104: 509-523.

Mutti, E. 1992. Turbidite Sandstones.

Normark, W.R. and Piper, D.J.W. 1991. Initiation processes and flow evolution of turbidity currents: implications for the depositional record. SEPM Special Publication, 46: 207-229.

Piper, D.J.W. and Deptuck, M. 1997. Fine-grained turbidites of the Amazon Fan: facies characterization and interpretation. In: Proceedings of the Ocean Drilling Program, Scientific Results (Eds R.D. Flood, D.J.W. Piper, A. Klaus and L.C. Peterson), 155, pp. 79108.

Piper, D.J.W. and Normark, W.R. 1983. Turbidite Depositional Patterns and Flow Characteristics, Navy Submarine Fan, California Borderland. Sedimentology, 30: 681-694.

Rasmussen, E.S. 1996. Structural evolution and sequence formation offshore South Gabon during the Tertiary. Tectonophysics, 266: 509.

Savoye, B., Cochonat, P., Apprioual, R., Bain, O., Baltzer, A., Bellec, V., Beuzart, P., Bourillet, J.F., Cagna, R., Cremer, M., Crusson, A., Dennielou, B., Diebler, D., Droz, L., Ennes, J.C., Floch, G., Foucher, J.P., Guiomar, M., Harmegnies, F., Kerbrat, R., Klein, B., Khun, H., Landure, J.Y., Lasnier, C., Le Drezen, E., Le Formal, J.P., Lopez, M., Loubrieu, B., Marsset, T., Migeon, S., Normand, A., Nouze, H., Ondreas, H., Pelleau, P., Saget, P., Seranne, M., Sibuet, J.C., Tofani, R. and Voisset, M. 2000. Structure et évolution récente de l'éventail turbiditique du Zaïre: premiers résultats scientifiques des missions d'exploration ZaiAngo 1 \& 2 (Marge Congo-Angola). Comptes-Rendus de l'Académie des Sciences de la Terre, 331: 211-220.

Séranne, M. and Anka, Z. 2005. South Atlantic continental margins of Africa: A comparison of the tectonic vs climate interplay on the evolution of equatorial west Africa and SW Africa margins. Journal of African Earth Sciences, 43: 283. 
Seranne, M., Seguret, M. and Fauchier, M. 1992. Seismic super-units and post-rift evolution of the continental passive margin of southern Gabon. Bulletin de la Societe Geologique de France, 163: 135-146.

Shepard, F.P. and Emery, K.O. 1973. Congo submarine canyon and fan valley. AAPG Bulletin, 57: 1679-1691.

Showers, J.W., Scheinder, R., Mikkelsen, N. and Maslin, M. 1997. Isotopic stratigraphy of Amazon fan sediments. In: Proceedings of the Ocean Drilling Program, Scientific Results (Eds R.D. Flood, D.J.W. Piper, A. Klaus and L.C. Peterson), 155, pp. 281-303. Ocean Drilling Program, College Station, TX.

Skene, K.I., Piper, D.J.W. and Hill, P.S. 2002. Quantitative analysis of variations in depositional sequence thickness from submarine channel levees. Sedimentology, 49: 1411-1430.

Stuiver, M., Reimer, P. J., Bard, E., Beck, J. W., Burr, G. S., Hughen, K. A., Kromer, B., McCormac, G., van der Plicht, J., and Spurk, M. (1998). INTCAL98 Radiocarbon Age Calibration, 24000-0 cal BP. Radiocarbon 40, 1041-1083.

Syvitski, J.P.M. and Hein, F.J. 1991. Sedimentology of an artic basin: Itirbilung Fjord, Baffin Island, Northwest Territories. Geological Survey of Canada Paper, 91: 67.

Teisserenc, P. and Villemin, J. 1989. Sedimentary Basin of Gabon, Geology and Oil System. In: Divergent / Passive Margin Basins (Eds Edwards and Santogrossi), 48, pp. 117-199. AAPG Memoir.

Uchupi, E. 1989. The tectonic style of the Atlantic Mesozoic rift system. Journal of African Earth Sciences, 8: 143.

Uchupi, E. 1992. Angola Basin: Geohistory and Construction of the Continental Rise. In: Geologic Evolution of Atlantic Continental Rifts (Eds Poag and D. Graciansky), pp. 77-99. Nostrand Reinhold, New York.

Uenzelmann-Neben, G., Spiess, V. and Bleil, U. 1997. A Seismic Reconnaissance Survey of the Northern Congo Fan. Marine Geology, 140: 283-306.

Van Weering, T.C.E. and Van Iperen, J. 1984. Fine-grained sediments of the Zaire deep-sea fan, southern Atlantic Ocean. In: Fine-grained Sediments: Deep-Water Processes and Facies (Eds D.A.V. Stow and D.J.W. Piper), 15, pp. 95-113. Geological Society Special Publication.

Walker, R.G. 1978. Deep-water sandstone facies and ancient submarine fans: models for exploration for stratigraphic traps. AAPG Bulletin, 62: 932-966.

Wefer, G., Berger, W.H. and Richter, C. 1998. Proc. ODP Initial Reports, 175. Ocean Drilling Program, College Station, TX.

Wetzel, A. 1993. The transfer of river load to deep-sea fans: A quantitative approach. AAPG Bulletin, 77: 1679-1692.

Winker, C.D. 1996. High resolution seismic stratigraphy of the late Pleistocene submarine fan poinded by salt withdrawal mini-basin on the Gulf of Mexico Continental Slope. In: Offshore Technology Conference (Ed OTC), pp. 619-628, Houston, Texas.

Wonham, J.P., Jayr, S., Mougamba, R. and Chuilon, P. 2000. 3D sedimentary evolution of a 
canyon fill (Lower Miocene-age) from the Mandorove Formation, offshore Gabon. Marine and Petroleum Geology, 17: 175-197. 


\begin{tabular}{|c|c|c|c|c|c|c|c|c|}
\hline Core & $\begin{array}{c}\text { Depth in core } \\
\text { (mbsf) }\end{array}$ & $\begin{array}{l}\text { Conventional age } \\
\text { (year BP) }\end{array}$ & Material & $+\grave{O}$ & $\begin{array}{l}\text { Calibrated age } \\
\text { (year BP) }\end{array}$ & $-\grave{O}$ & $\begin{array}{c}\text { Average } \\
\text { accumula } \\
\text { tion rates } \\
\text { in core } \\
\left(\mathrm{cm} \cdot \mathrm{ky}^{-1}\right)\end{array}$ & Analysis \# \\
\hline KZAI 01 & 1.90 & $8710 \pm 60$ & Bulk foraminifera & 9414 & 9072 & 9019 & & NIOZ \\
\hline KZAI 01 & 8.51 & $31800 \pm 400$ & Bulk foraminifera & - & $36518 *$ & - & 23.3 & NIOZ \\
\hline KZAI 03 & $2.50-2.54$ & $48400 \pm 2000$ & Carbonate bioclasts & \multicolumn{3}{|c|}{ No calibration } & 5.2 & LLNL-69554 \\
\hline KZAI 05 & $1.97-1.98$ & $7340 \pm 80$ & Vegetal debris & 8275 & 8167 & 8031 & & Lyon-976(OXA) \\
\hline KZAI 05 & $8.21-8.25$ & $9250 \pm 50$ & Vegetal debris & 10500 & 10451 & 10285 & 78.9 & LLNL-69647 \\
\hline KZAI 06 & $0.22-0.23$ & Post $17^{\text {th }}$ century & Vegetal debris & - & Modern & - & 57.5 & Lyon-977(OXA) \\
\hline KZAI 07 & $0.94-0.98$ & $900 \pm 40$ & Carbonate bioclasts & 530 & 509 & 489 & 186.6 & LLNL-69555 \\
\hline KZAI 13 & 6.00 & $3510 \pm 60$ & Vegetal debris & 3867 & 3773 & 3692 & & Lyon-986(OXA) \\
\hline KZAI 13 & $8.18-8.20$ & $4090 \pm 50$ & Vegetal debris & 4805 & 4549 & 4450 & & Lyon \\
\hline KZAI 13 & $12.97-13.01$ & $4300 \pm 40$ & Vegetal debris & 4867 & 4851 & 4833 & & LLNL-69654 \\
\hline KZAI 13 & 15.76 & $3430 \pm 50$ & Vegetal debris & 3809 & 3662 & 3613 & 430.4 & Lyon \\
\hline KZAI 15 & 0.17 & $810 \pm 50$ & Vegetal debris & 759 & 719 & 673 & & Lyon-988(OXA) \\
\hline KZAI 15 & 1.70 & $23650 \pm 390$ & Carbonate shell & - & 27 350* & - & 6.2 & Lyon-1034(OXA) \\
\hline KZR-12 & $7.40-7.41$ & $1735 \pm 40$ & Vegetal debris & 1707 & 1660 & 1568 & & LLNL-82209 \\
\hline KZR-23 & $1.50-1.60$ & $2395 \pm 45$ & Bulk foraminifera & 2084 & 2008 & 1961 & & LLNL-82201 \\
\hline KZR-23 & $16.88-16.93$ & $10500 \pm 40$ & Vegetal debris & 12809 & 12495 & 12337 & 135.5 & LLNL-82210 \\
\hline
\end{tabular}

Table 1 


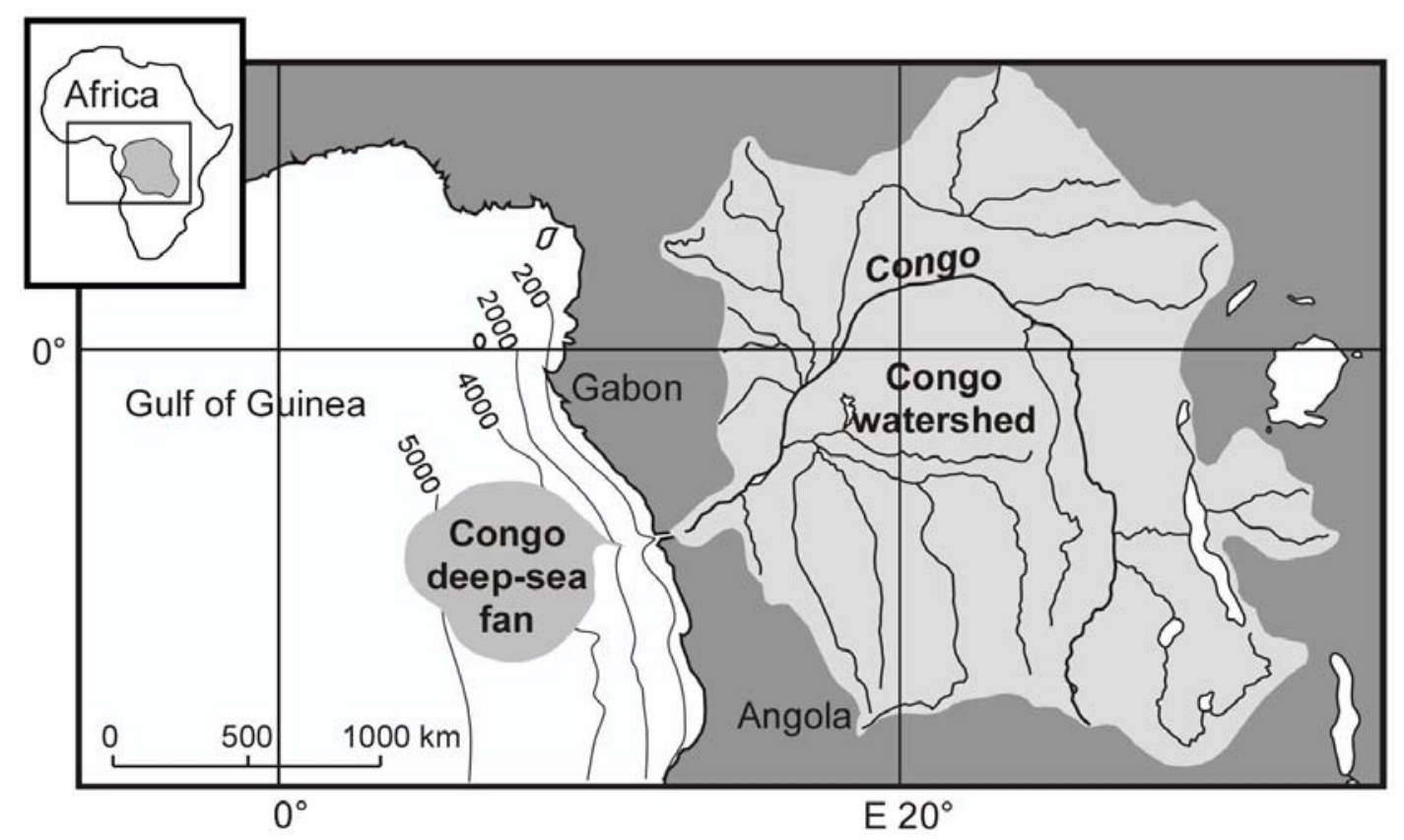

Figure 1 - Savoye et al, 2009 


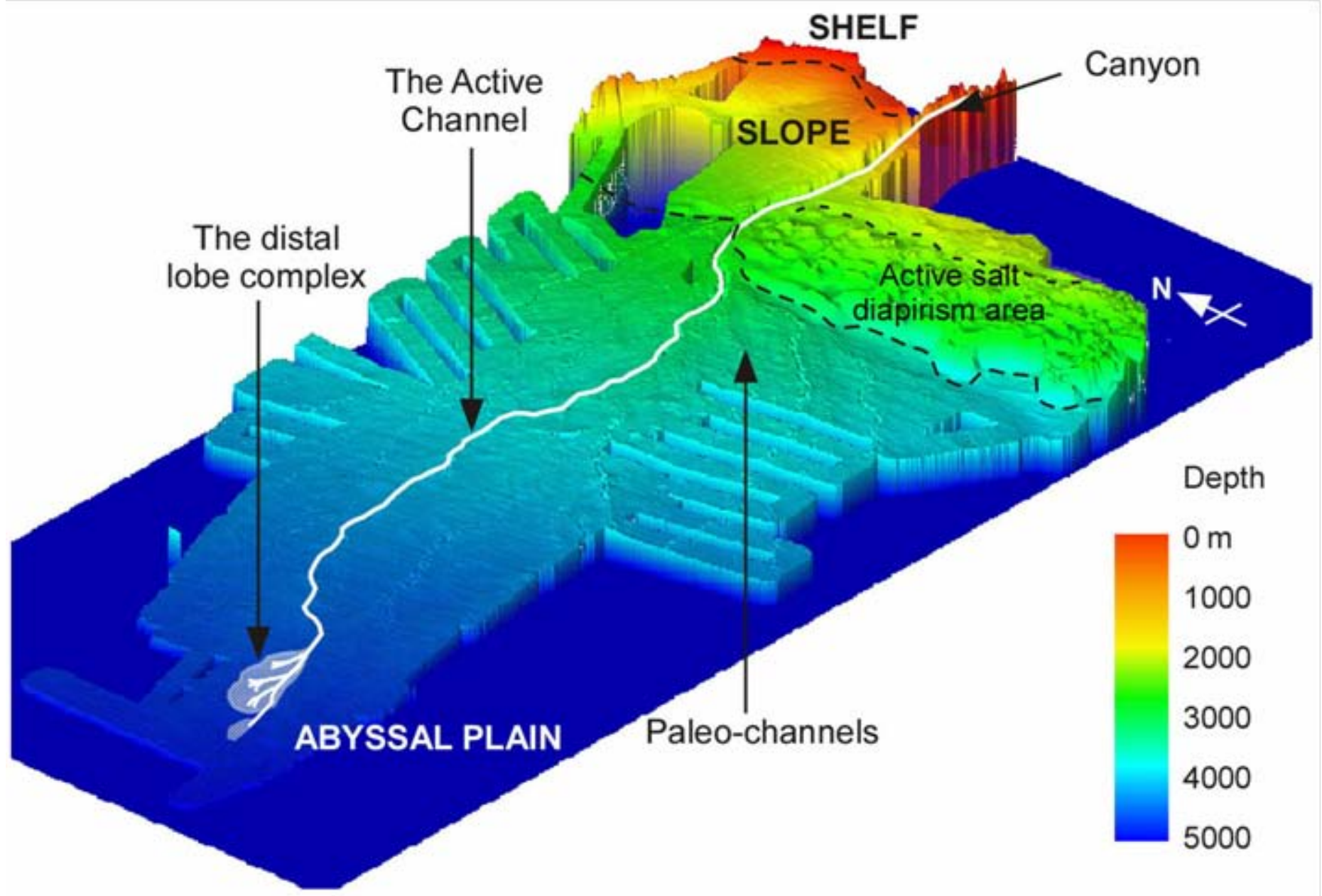

Figure 2 - Savoye et al, 2009 


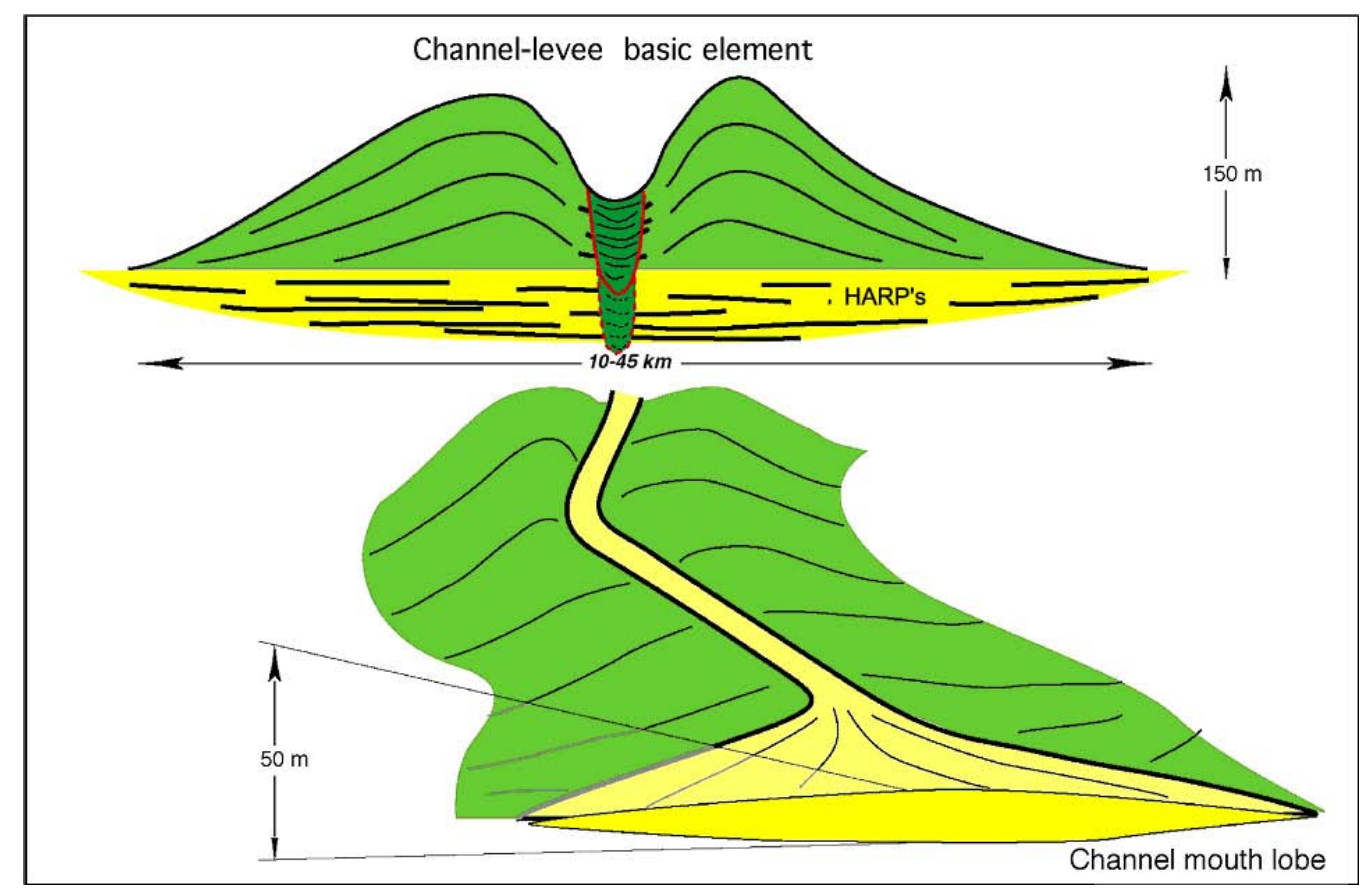

Figure 3 - Savoye et al, 2009 


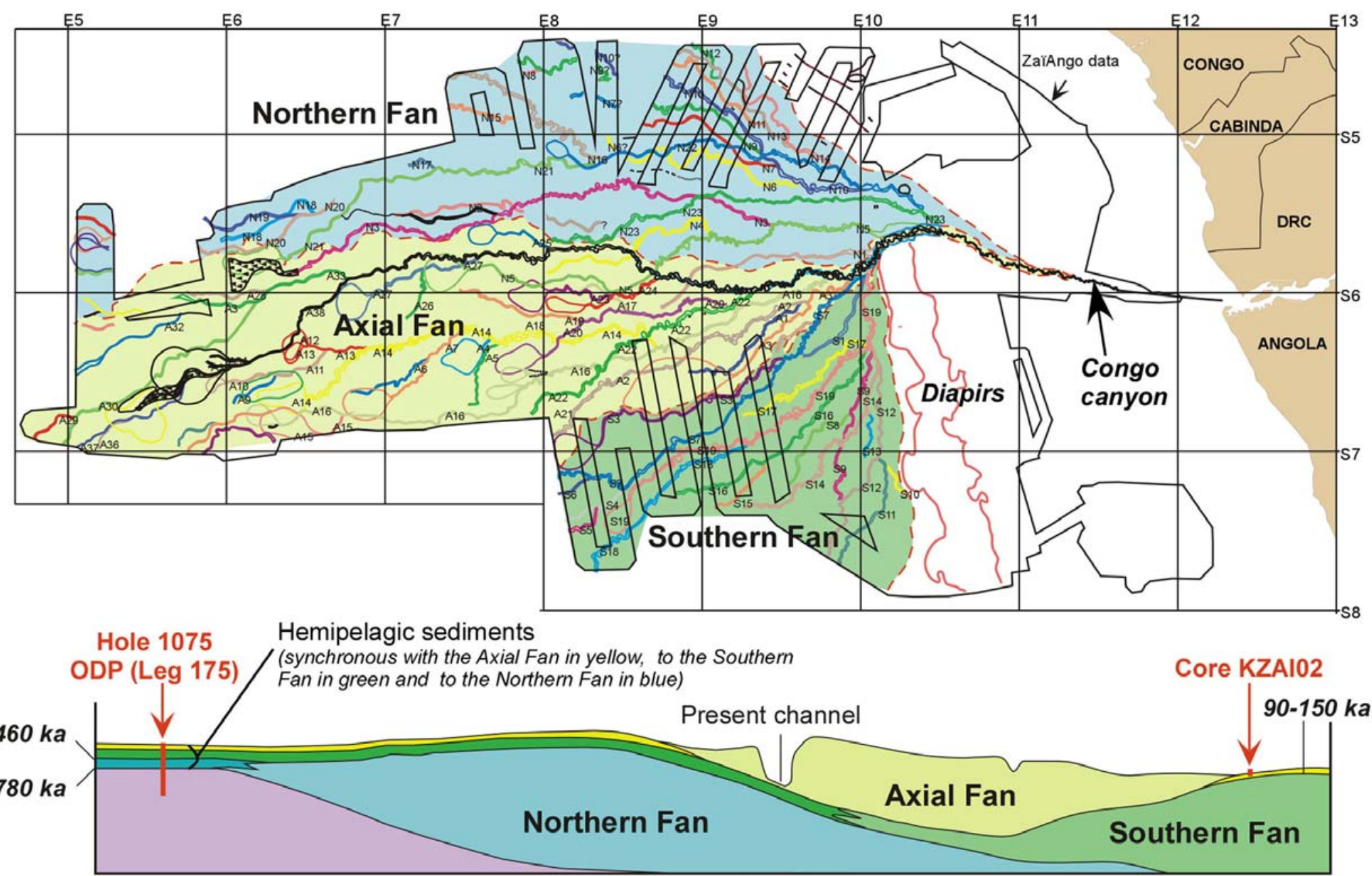

Figure 4 - Savoye et al, 2009 


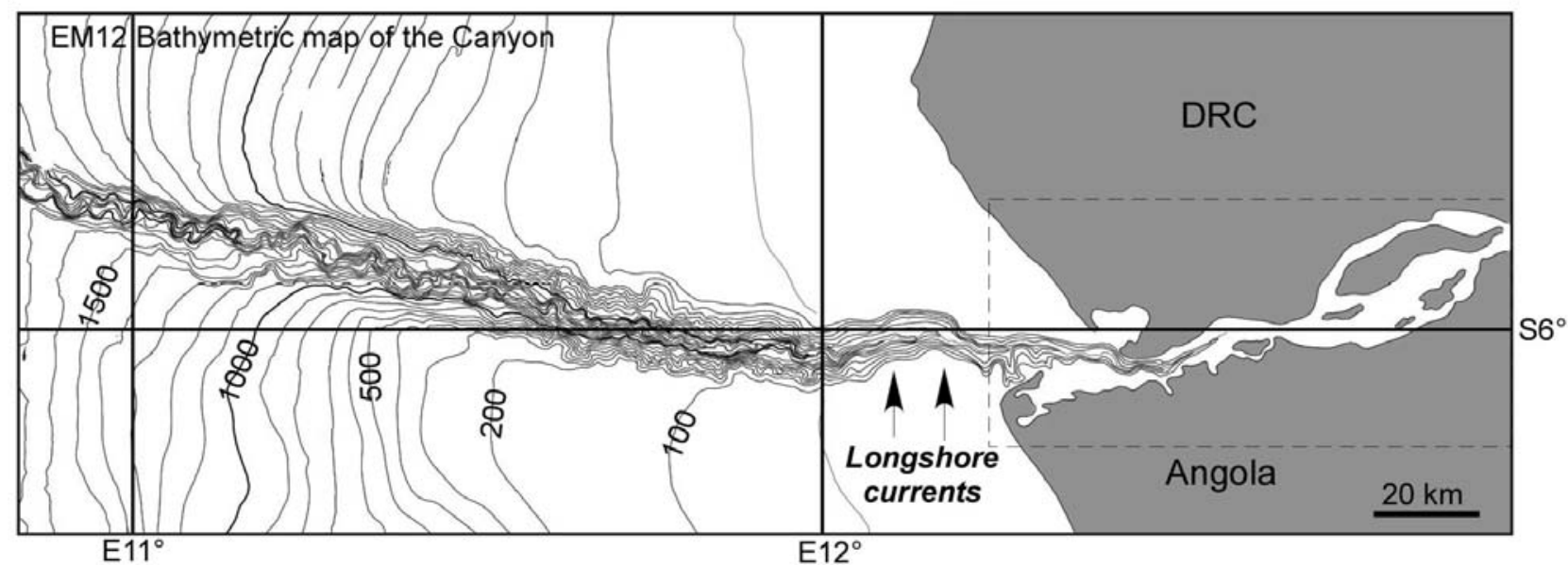

$\mathrm{E} 11^{\circ}$

$\mathrm{E} 12^{\circ}$

\begin{abstract}
Incised estuary by the canyon head, bordered by swampy areas
\end{abstract}

Shifting area, multiple distributary paths with shallow water depth (max. 6-7 m), prograding sand bars

River confined between high cliffs, water depth is locally very deep (> $150 \mathrm{~m})$, high energy and vortical flows

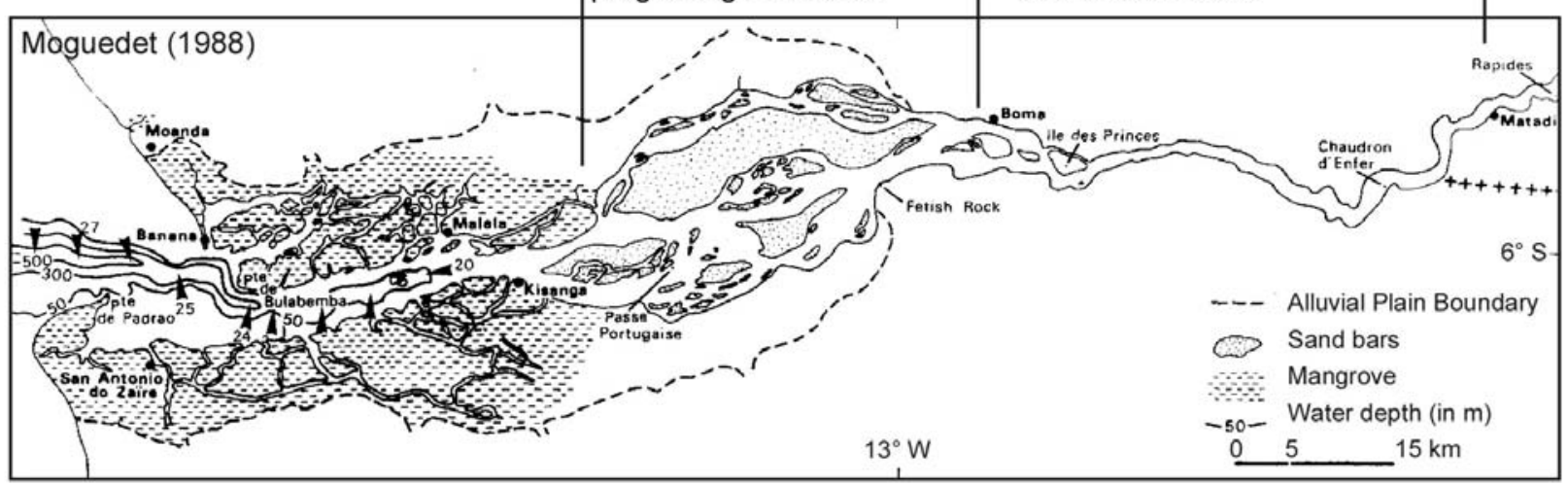

Figure 5 - Savoye et al, 2009 


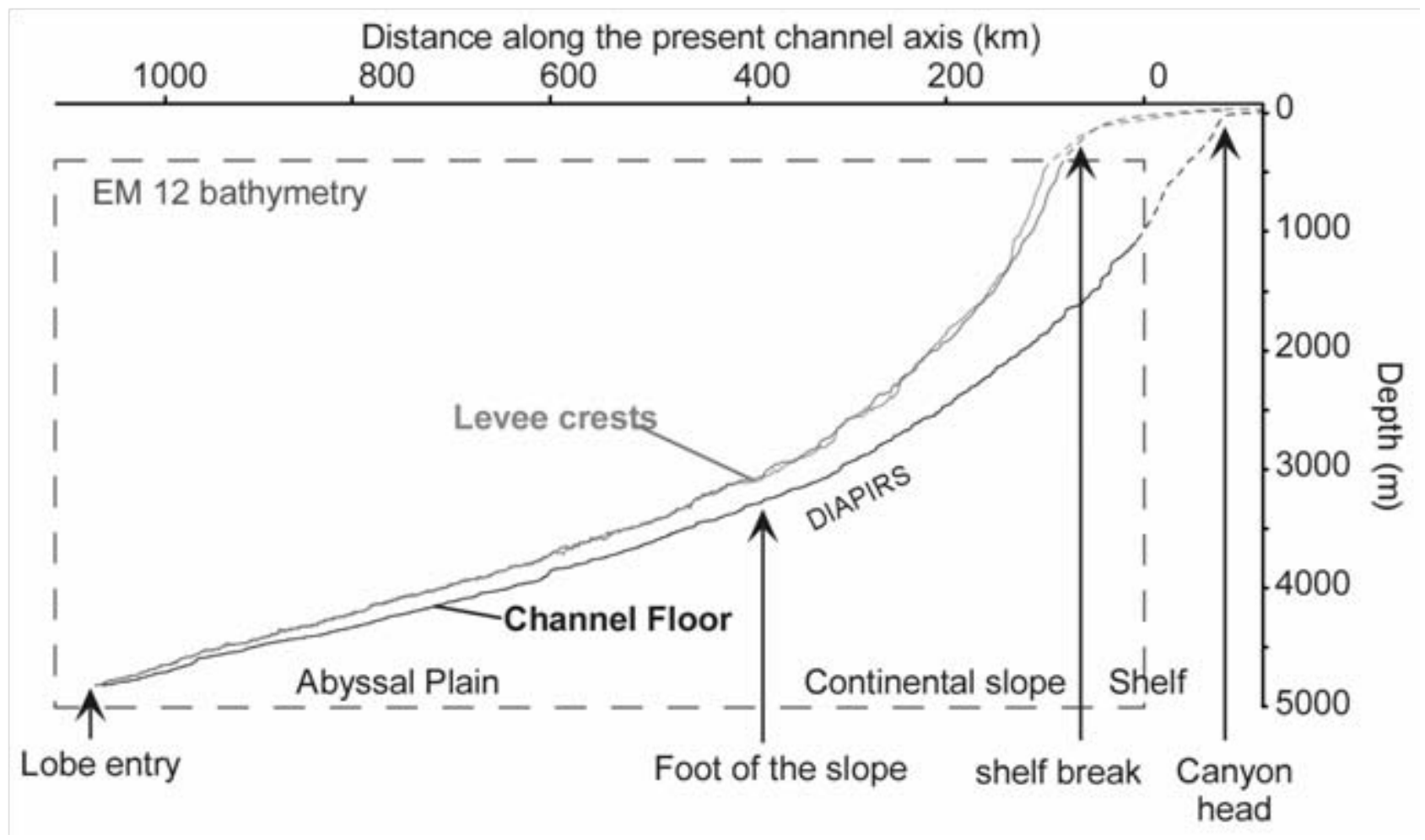

Figure 6 - Savoye et al, 2009 

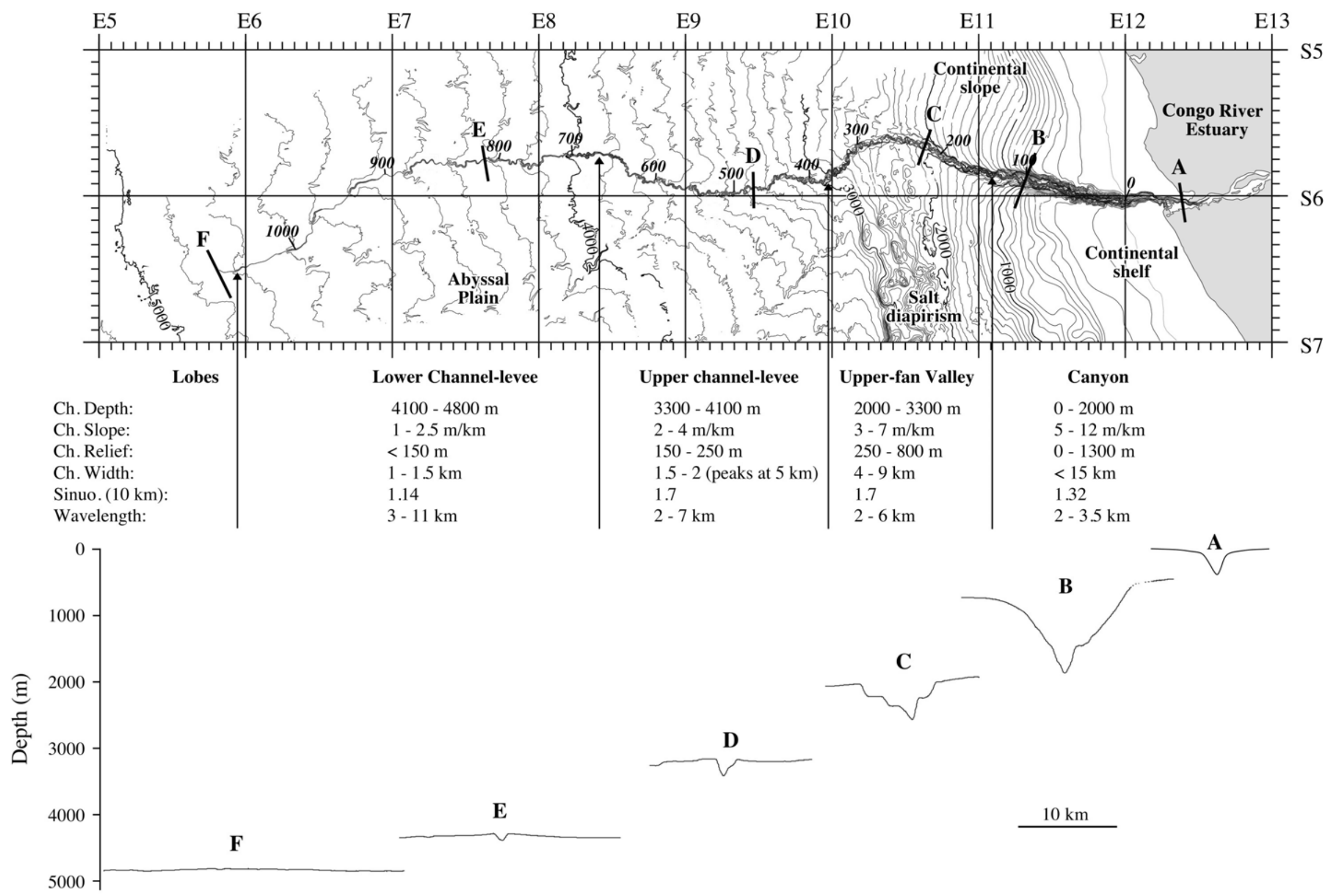

D

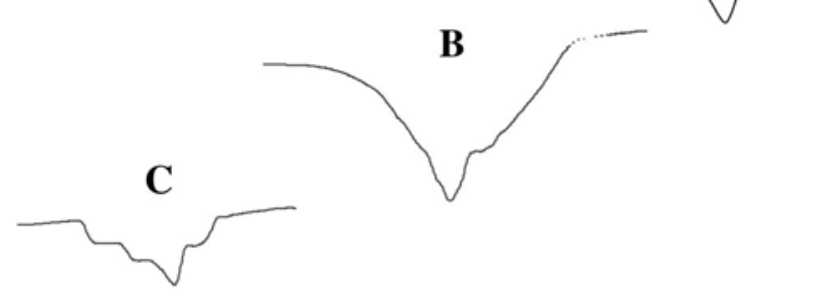

Figure 7 - Savoye et al, 2009 


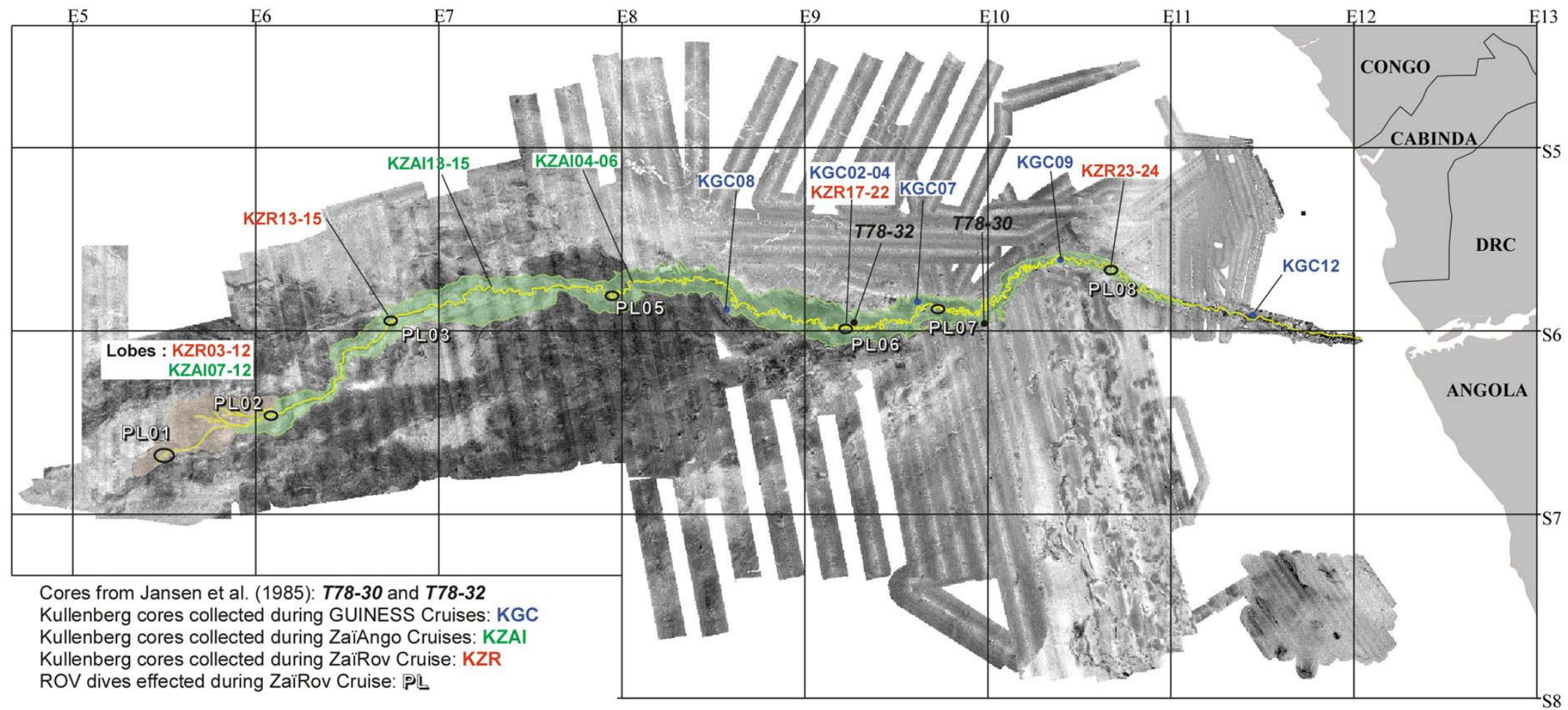

Figure 8 - Savoye et al, 2009 


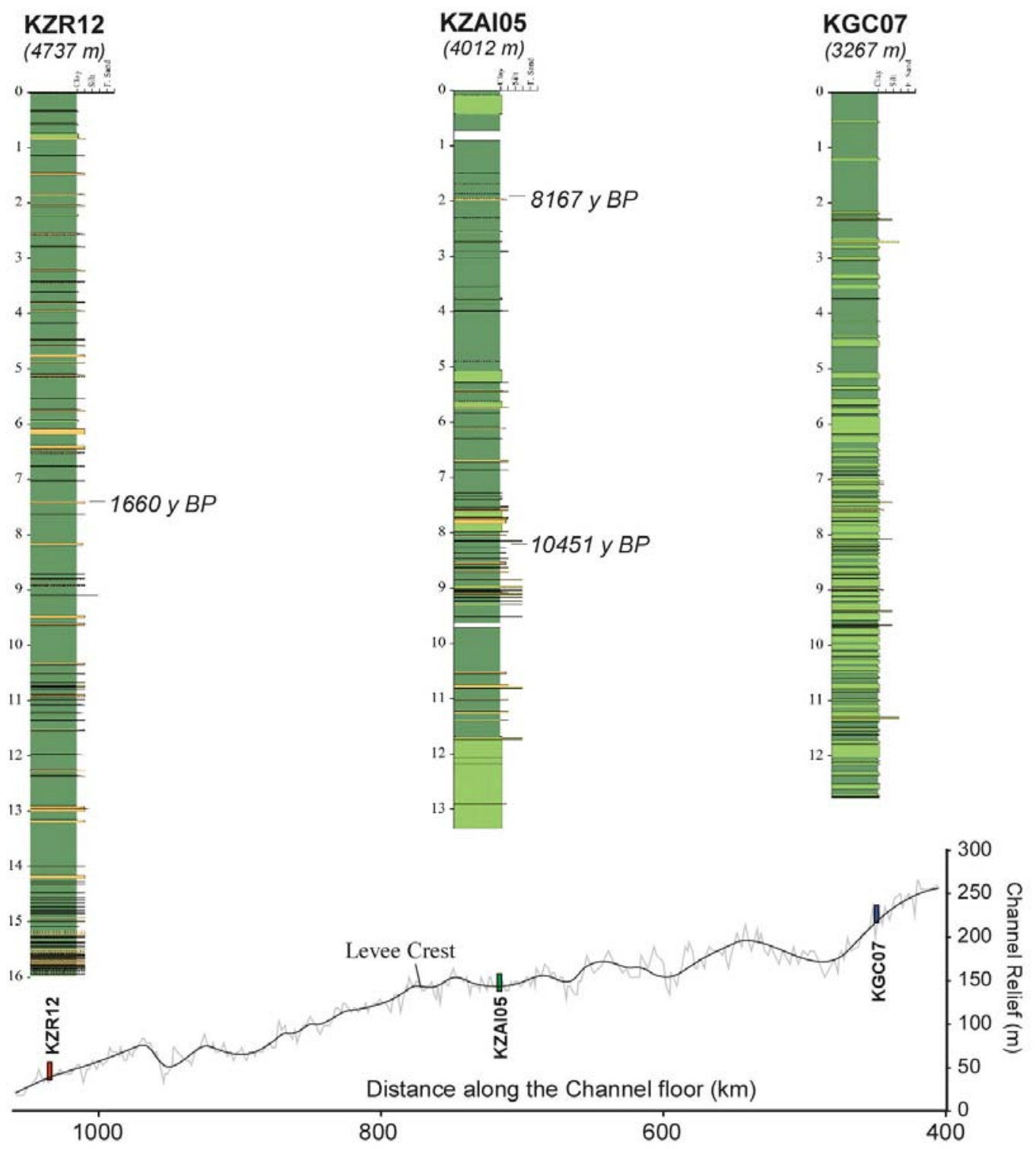

Figure 9 - Savoye et al, 2009 


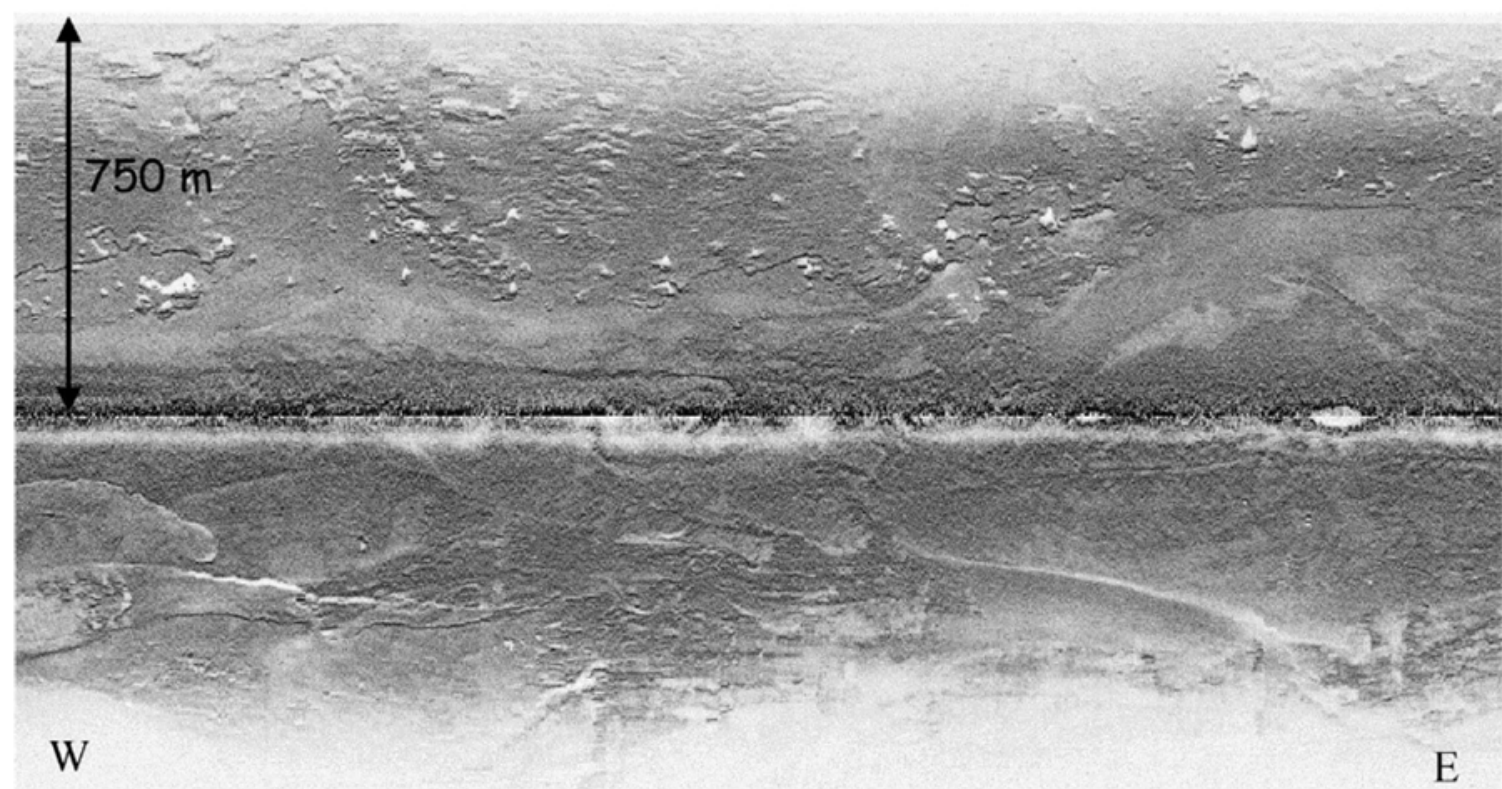

Figure 10 - Savoye et al, 2009 


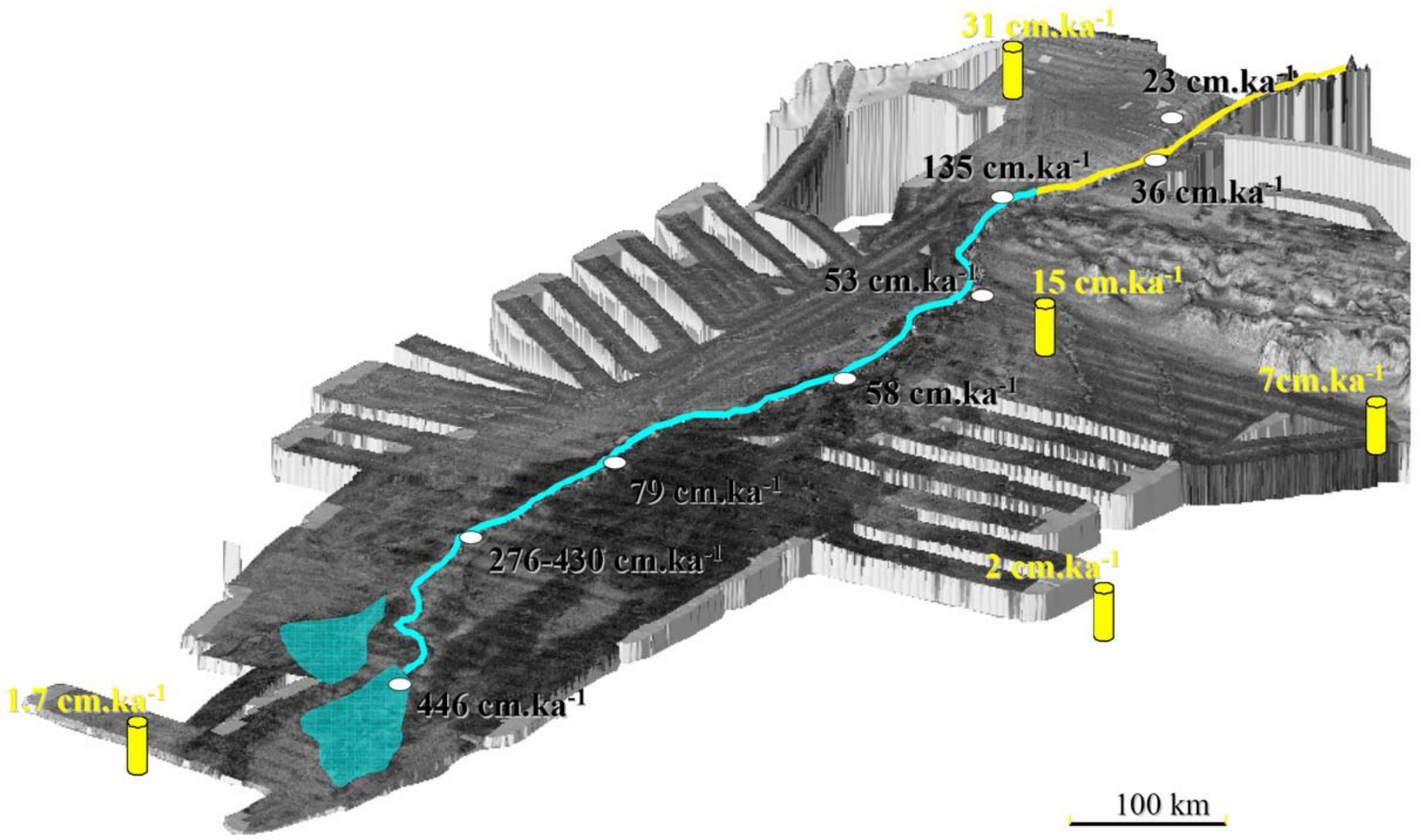

Figure 11 - Savoye et al, 2009 


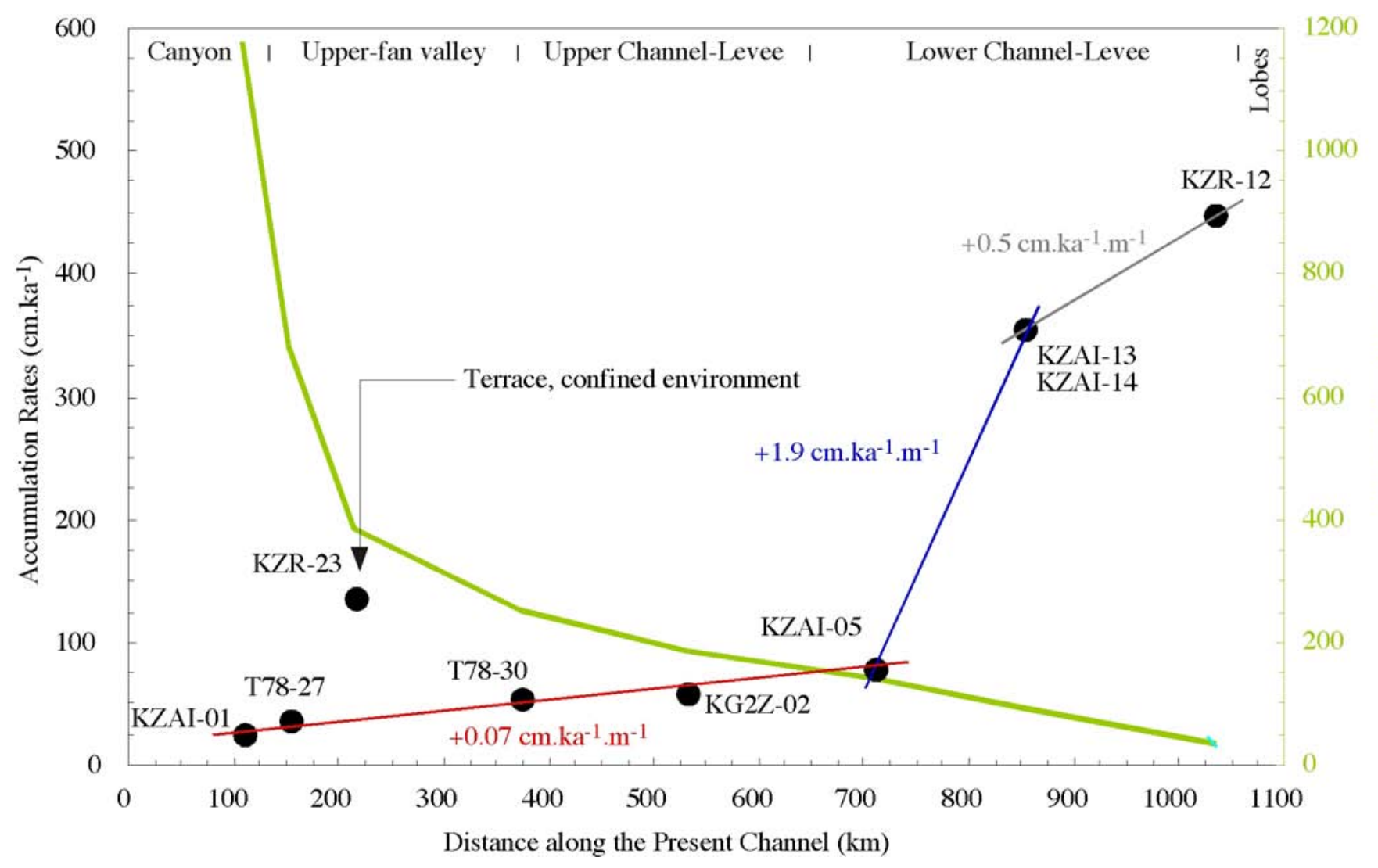

Figure 12 - Savoye et al, 2009 


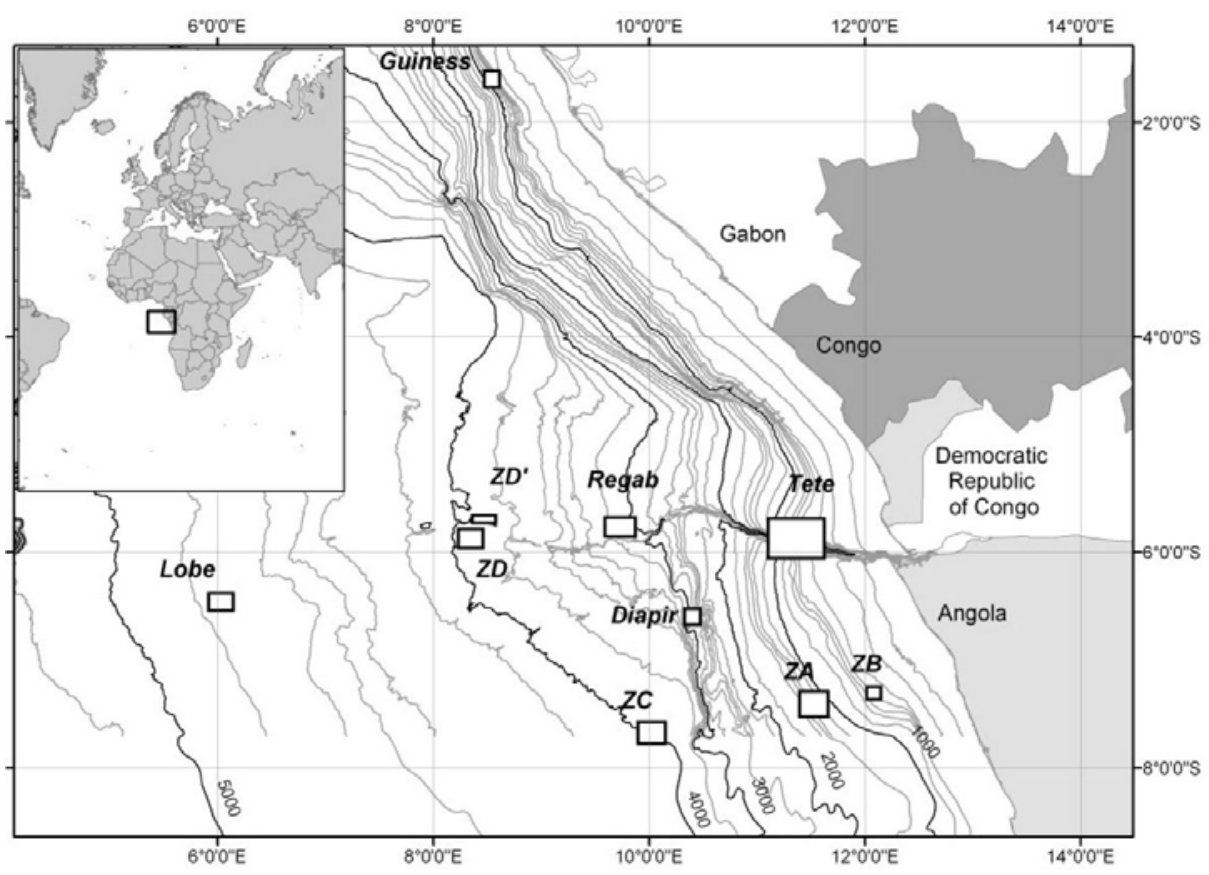

Figure 13 - Savoye et al, 2009 